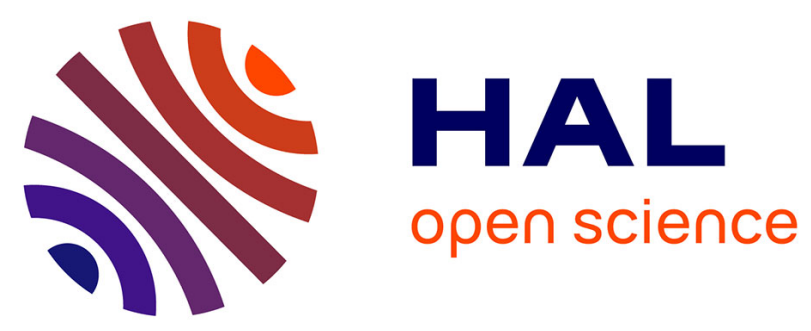

\title{
A Theranostic Agent Combining a Two-Photon-Absorbing Photosensitizer for Photodynamic Therapy and a Gadolinium(III) Complex for MRI Detection
}

Julie Schmitt, Valérie Heitz, Angélique Sour, Frédéric Bolze, Pascal Kessler, Lucia Flamigni, Barbara Ventura, Célia S. Bonnet, Éva Tóth

\section{To cite this version:}

Julie Schmitt, Valérie Heitz, Angélique Sour, Frédéric Bolze, Pascal Kessler, et al.. A Theranostic Agent Combining a Two-Photon-Absorbing Photosensitizer for Photodynamic Therapy and a Gadolinium(III) Complex for MRI Detection. Chemistry - A European Journal, 2016, 22 (8), pp.2775-2786. 10.1002/chem.201503433 . hal-01407691

\section{HAL Id: hal-01407691 \\ https://hal.science/hal-01407691}

Submitted on 31 Jan 2022

HAL is a multi-disciplinary open access archive for the deposit and dissemination of scientific research documents, whether they are published or not. The documents may come from teaching and research institutions in France or abroad, or from public or private research centers.
L'archive ouverte pluridisciplinaire HAL, est destinée au dépôt et à la diffusion de documents scientifiques de niveau recherche, publiés ou non, émanant des établissements d'enseignement et de recherche français ou étrangers, des laboratoires publics ou privés. 


\title{
A Theranostic Agent Combining a Two-Photon-Absorbing Photosensitizer for Photodynamic Therapy and a Gadolinium(III) Complex for MRI Detection
}

\author{
Julie Schmitt, ${ }^{[a]}$ Valérie Heitz, ${ }^{*[a]}$ Angélique Sour, ${ }_{,}^{[a]}$ Frédéric Bolze, ${ }^{*[b]}$ Pascal Kessler, ${ }^{[c]}$ \\ Lucia Flamigni, ${ }^{[d]}$ Barbara Ventura, ${ }^{*[d]}$ Célia S. Bonnet, ${ }^{[e]}$ and Éva Tóth ${ }^{*[e]}$
}

\begin{abstract}
Prof., Prof. Dr., Dr.) for the authors The convergent synthesis and characterization of a potential theranostic agent, [DPP-ZnP$\mathrm{GdDOTA}^{-}$, which combines a diketopyrrolopyrrole-porphyrin component DPP-ZnP as a two-photon photosensitizer for photodynamic therapy (PDT) with a gadolinium(III) DOTA complex as a magnetic resonance imaging probe, is preseented. [DPP-ZnP-GdDOTA] ${ }^{-}$has a remarkably high longitudinal water proton relaxivity $\left(19.94 \mathrm{~mm}^{-1} \mathrm{~s}^{-1}\right.$ at $20 \mathrm{MHz}$ and $25^{\circ} \mathrm{C}$ ) for a monohydrated molecular system of this size. The nuclear magnetic relaxation dispersion (NMRD) profile is characteristic of slow rotation, related to the extended and
\end{abstract}

rigid aromatic units integrated in the molecule and to selfaggregation occurring in aqueous solution. The two-photon properties were examined and large two-photon absorption cross-sections around $1000 \mathrm{GM}$ were determined between 910 and $940 \mathrm{~nm}$ in dichloromethane (DCM) with $1 \%$ pyridine and in DMSO. Furthermore, the new conjugate was able to generate singlet oxygen, with quantum yield of 0.42 and 0.68 in DCM with $1 \%$ pyridine and DMSO, respectively. Cellular studies were also performed. The [DPP-ZnPGdDOTA $]^{-}$conjugate demonstrated low dark toxicity and was able to induce high one-photon and moderate twophoton phototoxicity on cancer cells.

\section{Introduction}

The combination of therapy and diagnosis has led to a new field of research named theranostics, the aim of which is to develop mild, efficient, and personalized treatments. Associating an imaging modality to a therapeutic agent offers a promising way to improve treatment by monitoring in vivo the delivery and/or the effect of a drug. Several strategies have been pro-

[a] J. Schmitt, V. Heitz, A. Sour

Laboratoire de Synthèse des Assemblages Moléculaires Multifonctionnels, Institut de Chimie de Strasbourg, CNRS/UMR 7177, Université de Strasbourg, 4, rue Blaise Pascal, 67000 Strasbourg (France)

E-mail:v.heitz@unistra.fr

[b] F. Bolze

CAMB, UMR 7199, UdS/CNRS, Faculté de Pharmacie

Université de Strasbourg, 74 route du Rhin, 67401 IIIkirch (France)

E-mail:frederic.bolze@unistra.fr

[c] P. Kessler

Institute of Genetics and Molecular and Cellular Biology

1, rue Laurent Fries, 67404 Illkirch (France)

[d] L. Flamigni, B. Ventura

Istituto ISOF-CNR, Via P. Gobetti 101, 40129 Bologna (Italy)

E-mail: barbara.ventura@isof.cnr.it

[e] C. S. Bonnet, É. Tóth

Centre de Biophysique Moléculaire UPR4301, CNRS, Université d'Orléans, rue Charles Sadron, 45071 Orléans (France)

E-mail:eva.jakabtoth@cnrs-orleans.fr

$\square$ Supporting information for this article is available on the WWW under http://dx.doi.org/10.1002/chem.201503433. posed to obtain theranostic agents based on molecular systems as well as on nanoparticles. ${ }^{[1]}$

As a diagnostic tool, magnetic resonance imaging (MRI) is widely used in medicine. It is a non-invasive modality, which provides images with excellent anatomical and temporal resolution. A disadvantage of this technique, however, is its low sensitivity requiring high concentrations of the contrast agents to be injected. ${ }^{[2]}$ Commercial contrast agents, based on paramagnetic gadolinium complexes, are extracellular and have low MRI efficiency. Their relaxivities, which measure the paramagnetic enhancement of the longitudinal water proton relaxation rate, are only in the order of $4-5 \mathrm{~mm}^{-1} \mathrm{~s}^{-1}$. ${ }^{[3]}$ These values could be significantly improved by optimizing the parameters that influence relaxivity of the Gd"II complexes, such as the hydration number, the water exchange rate or the rotational dynamics, by structural modifications. ${ }^{[4]}$

Photodynamic therapy (PDT) is a minimally invasive therapy, based on the localized light activation of a photosensitizer that reacts with surrounding oxygen to produce singlet oxygen or cytotoxic oxygen reactive species ${ }^{[5]}$ produced by energy or electron transfer from the triplet excited state of the photosensitizer. Although it is frequently applied to various skin diseases, age-related macular degeneration and cancerous tumors, it suffers from several limitations. These involve low tissue penetration of the visible light currently used in PDT, and photodamage induced by the excitation light outside the therapeutic window (between 700 and $1000 \mathrm{~nm}$ ), which is absorbed by various endogenous chromophores. Recently, PDT based on 
two-photon excitation of a photosensitizer performed in the near infrared region with short focalized laser pulses has proven to be a promising approach to circumvent those limitations. $^{[6]}$

The design of theranostic agents that combine MRI detection capabilities with two-photon sensitization ability for PDT is a further step towards a better control of this mild and efficient therapy. ${ }^{[7]}$ The most obvious benefit of such agents is indeed to monitor the delivery of the photosensitizer to the site of interest, to have a precise localization of the damaged area and to treat it with high spatial resolution by means of the combined imaging and therapeutic functions. Ideally, the conjugation of the MRI contrast agent to a porphyrin derivative, known to preferentially accumulate in tumor tissues, should not substantially change the biodistribution and the therapeutic agent will act as a vehicle to deliver the MRI agent to the area of the treatment. On the other hand, the chemical association of the photosensitizer to the MRI probe can also improve its relaxation properties. The increased size of the theranostic system as compared to the contrast agent alone will enhance its relaxivity by slowing down the rotational dynamics of the $\mathrm{Gd}^{\text {III }}$ center, provided that the whole molecule keeps a low inner flexibility. ${ }^{[3]}$ Moreover, the photosensitizer can benefit from the linkage with the $\mathrm{Gd}^{\text {III }}$ ion, which could promote intersystem crossing to the triplet state by heavy atom effect $^{[8]}$ and enhance the triplet yield. Finally, as each component (the $\mathrm{Gd}^{\text {III }}$ complex and the photosensitizer) retains its activity within the conjugate without a need of in vivo cleavage, the real-time monitoring of not only the delivery but also the excretion of the theranostic agent becomes possible.

Few molecular systems consisting of $\mathrm{Gd}^{\mathrm{III}}$ complexes associated to a porphyrin derivative used as a one-photon photosensitizer for PDT have been reported to behave both as MRI contrast agents and singlet oxygen generators. ${ }^{[9]}$ In those examples, the relaxivity of the contrast agent constructed on a porphyrin core was greatly affected by the size and flexibility of the whole molecule. Various strategies have also been proposed to assemble high concentrations of the MRI probe and of the photosensitizer in a nanoparticle. ${ }^{[10]}$ However, their random proportion renders the pharmacokinetics of such systems difficult to predict. For the molecular PDT-MRI conjugate systems reported so far, the optimization of the PDT sensitizer component remains to be done, in particular in terms of lowering the excitation energy close to the therapeutic window (700-1000 nm) to achieve higher penetration depth in tissues. This can be pursued mainly by two approaches: 1) by lowering the HOMO-LUMO gap of the sensitizer through an appropriate chemical modification, or 2) by using a sensitizer with high two-photon absorption (TPA) cross-section in the therapeutic window. The application of a two-photon sensitizer implies also the advantages inherent to the TPA phenomenon, that is, increased spatial resolution of the treatment and decreased photodamage of the surrounding tissues. ${ }^{[6 \mathrm{~g}]}$

Following the second strategy, we herein describe the convergent synthesis of the theranostic agent [DPP-ZnP-GdDOTA $]^{-}$ that associates a diketopyrrolopyrrole-zinc(II) porphyrin component as two-photon absorbing photosensitizer for PDT with
GdDOTA as MRI probe $\left(\mathrm{H}_{4} \mathrm{DOTA}=1,4,7,10\right.$-tetraazacyclododecane-1,4,7,10-tetraacetic acid). We have evaluated the twophoton absorption properties, the singlet oxygen generation as well as the relaxivity of the new conjugate in solution. Cell penetration and two-photon excitation experiments in cells have been carried out to assess its potential as a near-IR twophoton PDT photosensitizer.

\section{Results and Discussion}

The design of the theranostic system [DPP-ZnP-GdDOTA] ${ }^{-}$was based on a convergent synthesis that couples in the last step two well-defined components, a diketopyrrolopyrrole-zinc(II)porphyrin component, DPP- $\mathrm{ZnP}-\mathrm{NH}_{2}$, decorated with hydrophilic oligoethylene glycol chains, and an anionic [GdDOTA$\mathrm{GA}]^{2-}$ complex, which provides sufficient water solubility to the final compound for biological applications (Figure 1). The use of a diketopyrrolopyrrole-porphyrin conjugate as a component of the theranostic agent was motivated by our recent studies on a related conjugate, DPP-ZnP-TIPS. This robust dye has a large delocalized $\pi$-system and showed high TPA crosssection in the near-IR. ${ }^{[11]}$ Furthermore, it generated efficiently singlet oxygen in solution, penetrated readily in cells, and exhibited high two-photon induced phototoxicity on HeLa cell cultures.

The final hetero-dinuclear [DPP-ZnP-GdDOTA $]^{-}$complex, incorporating a $\mathrm{Zn}^{\prime \prime}$ in the porphyrin and a $\mathrm{Gd}^{\prime \prime \prime}$ in the DOTA chelate, could be conceived from the pre-metalated macrocyclic ligands by a careful choice of the reaction conditions to avoid demetalation of these acid-sensitive complexes. An amide bond formation in mild conditions was able to satisfy these requirements. The DPP-ZnP-NH $\mathrm{N}_{2}$ component can be readily obtained from DPP-ZnP-TIPS (Figure 2). ${ }^{[1]}$ The $\left[\right.$ GdDOTAGA] ${ }^{2-}$ precursor contains a DOTA-like ligand, a common macrocyclic chelator for gadolinium(III)-based contrast agents that provides high thermodynamic stability, kinetic inertness, and fast water exchange. ${ }^{[3]}$ In $\mathrm{H}_{5}$ DOTAGA, one of the acetate pendant arms is functionalized with an additional carboxylic acid. Gd"' complexation of [DOTAGA $]^{5-}$ involves four carboxylates and the remaining carboxylate of [GdDOTAGA $]^{2-}$ allows further reaction without using a protection/deprotection step. ${ }^{[12]}$ The [YDOTA$\mathrm{GA}]^{2-}$ complex was also synthesized and used to prepare the [DPP-ZnP-YDOTA $^{-}$conjugate, as the diamagnetic analogue of the desired paramagnetic [DPP-ZnP-GdDOTA $]^{-}$molecule (Figure 2).

The DPP-ZnP-NH $\mathrm{N}_{2}$ component was obtained in two steps from DPP-ZnP-TIPS. After classical cleavage of the triisopropyl silyl group using TBAF, the air-sensitive intermediate DPP-ZnP$\mathrm{H}$ was reacted with the tert-butoxycarbonyl (Boc)-protected 3iodobenzylamine ${ }^{[13]}$ under standard Sonogashira cross-coupling reaction conditions. Purifications with silica gel chromatography $\square$ ok? and size-exclusion column chromatography led to DPP-ZnP-NHBoc in $42 \%$ yield. Removal of the Boc-protecting group using trifluoroacetic acid led to partial demetalation of the zinc(II) porphyrin, which was remetalated with $\mathrm{Zn}(\mathrm{OAC})_{2} \cdot 2 \mathrm{H}_{2} \mathrm{O}$ to afford DPP-ZnP-NH $\mathrm{N}_{2}$ in almost quantitative yield. 


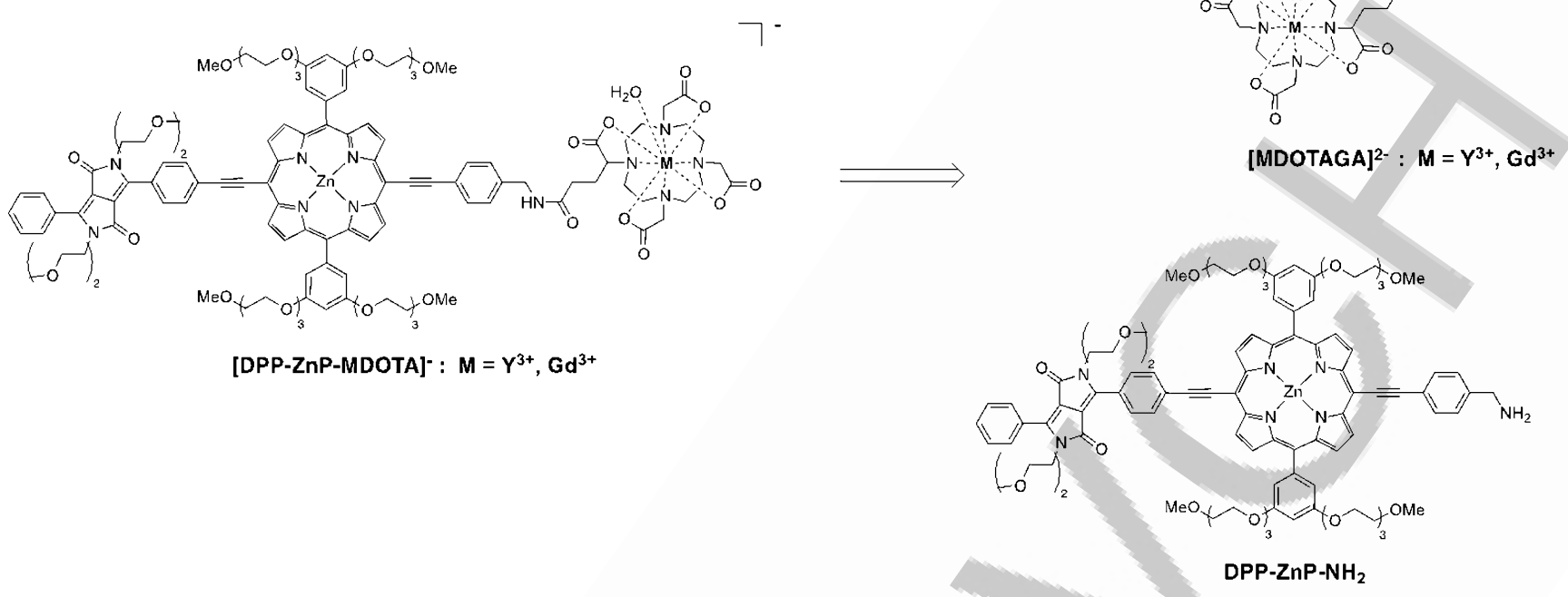

Figure 1. Synthetic strategy to prepare the theranostic system [DPP-ZnP-GdDOTA ${ }^{-}$from two components, DPP-ZnP-NH 2 and $[G d D O T A G A]^{2-}$. The related diamagnetic complex [DPP-ZnP-YDOTA $]^{-}$and its precursors are also represented.

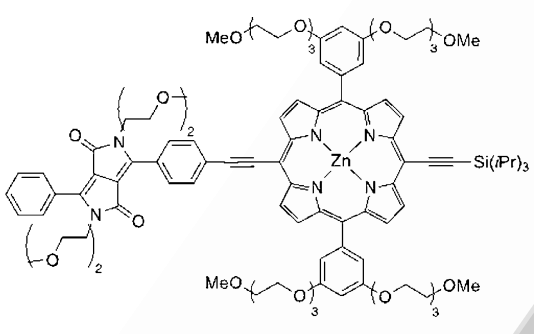

DPP-ZnP-TIPS

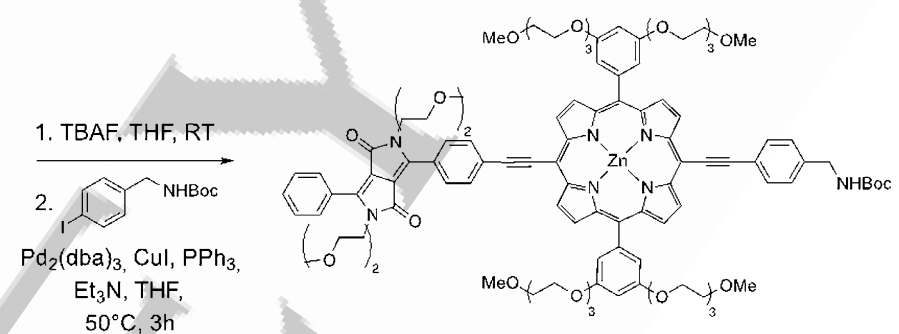

DPP-ZnP-NHBoc

$42 \%$

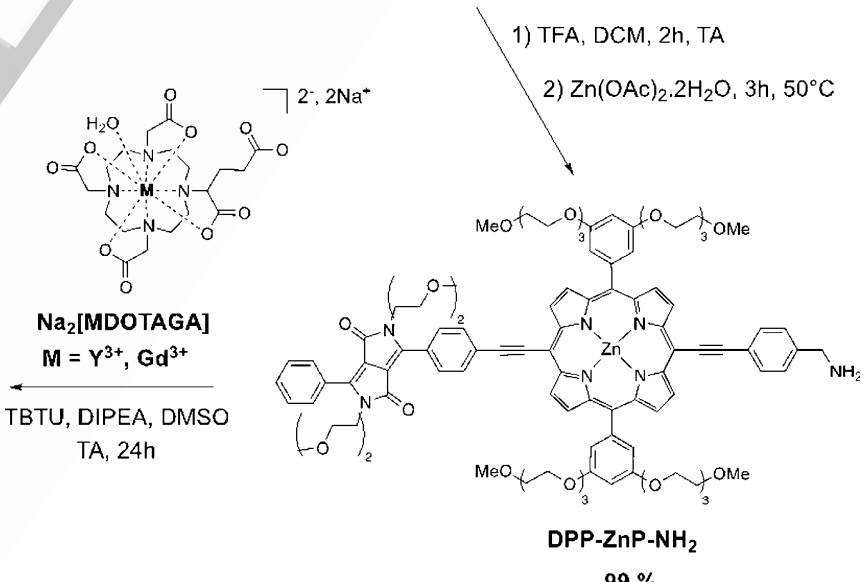

$99 \%$

Figure 2. Synthesis of $\mathrm{Na}[\mathrm{DPP}-\mathrm{ZnP}-\mathrm{MDOTA}], \mathrm{M}=\mathrm{Y}^{\mathrm{III}}$ or $\mathrm{Gd} \mathrm{d}^{\mathrm{III}}$.

The complexation of DOTAGA anhydride with $\mathrm{GdCl}_{3}$ at neutral $\mathrm{pH}$ adjusted with an aqueous sodium hydroxide solution gave the complex $\mathrm{Na}_{2}\left[\right.$ GdDOTAGA] as reported. ${ }^{[12]}$ The amide coupling reaction leading to the final [DPP-ZnP-GdDOTA $]^{-}$molecule was performed by using the sodium salt of the [GdDO-
TAGA $]^{2-}$ complex, dissolved in DMSO at $65^{\circ} \mathrm{C}$ before addition of the activating agent $O$-(benzotriazol-1-yl)- $N, N, N^{\prime}, N^{\prime}$-tetramethyluronium (N-TBTU) tetrafluoroborate, and the base $\mathrm{N}, \mathrm{N}$-diisopropylethylamine (DIPEA). Then a DMSO solution of DPP$\mathrm{ZnP}-\mathrm{NH}_{2}$ was added dropwise and the reaction mixture was 
stirred overnight at room temperature. Size-exclusion column chromatography allowed the removal of the coupling agents and unreacted starting porphyrin from the crude mixture.

The delicate purification of the final molecule was achieved by size-exclusion column chromatography followed by preparative TLC using $\mathrm{DCM} / \mathrm{MeOH} / \mathrm{NH}_{4} \mathrm{OH}$ 80:15:5 as eluent to afford the sodium salt Na[DPP-ZnP-GdDOTA] in $52 \%$ yield. The compound was characterized by high-resolution mass spectrometry. The isotopic profile of the molecular ionic species $[\mathrm{M}+2 \mathrm{Na}]^{+}$, detected at 2470.8131, was in accordance with the calculated one (Supporting Information, Figure S12). The related diamagnetic yttrium(III) complex $\mathrm{Na}$ [DPP-ZnP-YDOTA] obtained by reacting [YDOTAGA] ${ }^{2-}$ with DPP-ZnP-NH ${ }_{2}$ in similar reaction conditions as for [DPP-ZnP-GdDOTA $]^{-}$was further characterized with $1 \mathrm{D}$ and $2 \mathrm{D}{ }^{1} \mathrm{HNMR}$ spectroscopy in $\left[D_{6}\right]$ DMSO (Supporting Information, Figure S9 and S10).

\section{Relaxivity measurements}

To characterize the relaxation efficiency of the theranostic agent [DPP-ZnP-GdDOTA $]^{-}$, nuclear magnetic relaxation dispersion (NMRD) profiles were recorded in water at two different temperatures in the field range of $10 \mathrm{kHz}-600 \mathrm{MHz}$ (Figure 3). Some relaxivity data were also obtained in an aqueous solution containing $1 \%$ DMSO and were identical to those in water. Likewise, the relaxivities in the presence of $50 \mathrm{~mm} \mathrm{NaCl}$ were very similar to those measured in $\mathrm{H}_{2} \mathrm{O}$ alone (Supporting Information, Figure S14).

The most important parameters that influence relaxivity are the number of water molecules directly coordinated to the $\mathrm{Gd}^{\prime \prime \prime}(q)$, their exchange rate with the bulk water $\left(k_{\mathrm{ex}}\right)$, the rotational correlation time of the complex $\left(\tau_{\mathrm{R}}\right)$, and the parameters characterizing electron spin relaxation $\left(\tau_{v}\right.$ and $\left.\Delta^{2}\right)$. These parameters govern relaxivity via the Solomon-BloembergenMorgan (SBM) theory of paramagnetic relaxation. ${ }^{[3]}$ We assume that the $[\mathrm{DPP}-\mathrm{ZnP}-\mathrm{GdDOTA}]^{-}$complex has one inner-sphere

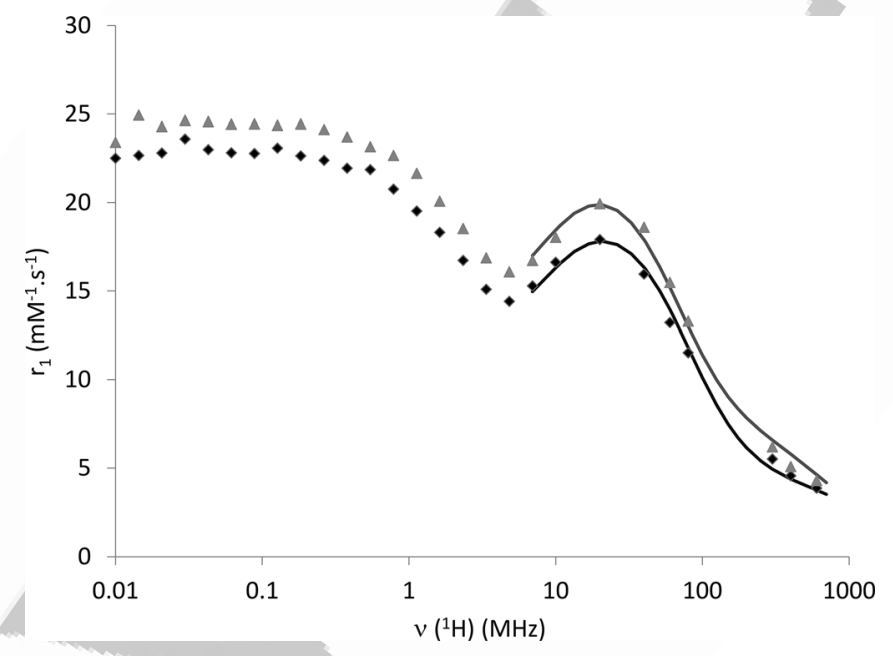

Figure 3. ${ }^{1} \mathrm{H}$ Nuclear magnetic relaxation dispersion (NMRD) profiles for [DPP-ZnP-GdDOTA] $]^{-}(1.13 \mathrm{~mm}, \mathrm{pH} 6.6)$ at $25^{\circ} \mathrm{C}(\mathbf{\Delta})$ and $37^{\circ} \mathrm{C}(\mathrm{v})$ in $\mathrm{H}_{2} \mathrm{O}$. The continuous lines represent the fitted curves. The $\mathrm{Gd}^{3+}$ content was determined by ICP-AES measurements. water molecule, analogously to GdDOTA and all similar DOTA derivatives. ${ }^{[3]}$

The relaxivity obtained for $[\mathrm{DPP}-\mathrm{ZnP}-\mathrm{GdDOTA}]^{-}, r_{1}=$ $19.94 \mathrm{~mm}^{-1} \mathrm{~s}^{-1}\left(20 \mathrm{MHz}, 25^{\circ} \mathrm{C}\right)$, is remarkably high for a molecular system of this size ( $\mathrm{MW}=2.4 \mathrm{kDa}$ ) incorporating one monohydrated GdDOTA complex. It is only slightly lower than the relaxivity of $\mathrm{P} 760\left(r_{1} \approx 25 \mathrm{~s}^{-1} \mathrm{~mm}^{-1}\right.$ between 20 and $\left.60 \mathrm{MHz}\right)$ with an approximately double molecular weight $(\mathrm{MW}=5.3 \mathrm{kDa})$, which was previously developed as a low diffusion, fast clearance blood pool agent. ${ }^{[14]}$ In P760, a GdDOTA core is decorated with four large (though not rigid) hydrophilic arms, thus the $\mathrm{Gd}^{\prime \prime \prime}$ is in the barycenter of the molecule and takes full advantage of the slow rotation of the entire system. The relaxivity of [DPP-ZnP-GdDOTA $]^{-}$is in the same order of magnitude as those reported for various nanosized objects such as MOFs, ${ }_{1}^{[15]}$ polyrotaxanes, ${ }^{[16]}$ micelles, ${ }_{1}^{[17]}$ and slightly lower than that of optimized gold nanoparticles. ${ }^{[18]}$ The relaxivity profiles display a high field peak with a maximum at around $20 \mathrm{MHz}$, which is characteristic of slow rotation (Figure 3 ). Such slow rotation is the result of the large size of our molecule integrating extended and rigid aromatic systems. Furthermore, a self-aggregation phenomenon occurring in aqueous solution is likely to further contribute to slow rotation. Indeed, self-aggregation is postulated on the basis of the photophysical properties of the conjugate in water (see below). The dilution of the circa $1 \mathrm{~mm}$ solution by a factor of two did not have detectable effect on the relaxivity. Water soluble tri- or tetra-anionic porphyrins are known to aggregate spontaneously ${ }^{[19]}$ and in the present [DPP$\left.\mathrm{ZnP}_{\mathrm{G}} \mathrm{GDOTA}\right]^{-}$system, the large extended $\pi$-conjugate system over the diketopyrrolopyrrole-zinc(II)porphyrin conjugate might favor intermolecular $\pi-\pi$ interactions. Self-aggregation resulting in high relaxivities has been often observed for medium-size systems consisting of several $\mathrm{Gd}^{\text {III }}$ complexes linked to an aromatic core. ${ }^{[20]}$ Nevertheless, despite the large size and the aggregation of [DPP-ZnP-GdDOTA $]^{-}$, the relaxivity is still limited by rotation and not by slow water exchange, as evidenced by the temperature dependency of the NMRD curves (the relaxivity decreases with increasing temperature).

To gain insight into the rotational dynamics of the system, the microscopic parameters characterizing rotation were assessed by fitting the experimental relaxivity data to the SBM theory. To take into account internal dynamics, we incorporated in the fit the Lipari-Szabo treatment often used to describe rotational motion of slow (ns) tumbling species. ${ }^{[21]}$ In this approach, the dipolar interactions between the Gd"I' electron spin and the water proton that generate the relaxation are influenced by both fast local rotational motion of the $\mathrm{Gd}^{3+}$-water proton axis, $\mathbf{\square}$ ok? $\mathbf{\square}$ characterized by the correlation time $\tau_{\mathrm{Rl}}$, and a slower, global motion (characterized by $\tau_{\mathrm{Rg}}$ ) that reflects the global motion of the system. The degree of spatial restriction of the local with respect to the global motion is measured by the generalized, model independent order parameter $S^{2}$. The value of $S^{2}$ ranges from 0 to 1 , with $S^{2}=0$ if the internal motions are isotropic, and $S^{2}=1$ if the internal motions are completely restricted. ${ }^{[3]}$

The fitting was restricted to frequencies above $6 \mathrm{MHz}$, as at low magnetic fields the SBM theory fails in describing electron- 
ic parameters and rotational dynamics of slowly rotating objects. In the fitting procedure, the number of water molecules directly coordinated to Gd"I was fixed to 1, and the water exchange rate constant and its activation enthalpy $\left(k_{\text {ex }}\right.$ and $\left.\Delta H^{\neq}\right)$ were fixed to values determined for GdDOTA. ${ }^{[22]}$ The diffusion constant and its activation energy were also fixed to $D_{\mathrm{GdH}}{ }^{298}=$ $26 \times 10^{-10} \mathrm{~m}^{2} \mathrm{~s}^{-1}$ and $E_{\mathrm{GdH}}=20 \mathrm{~kJ} \mathrm{~mol}^{-1}$. The best fit parameters obtained from the analysis of ${ }^{1} \mathrm{H}$ NMRD data are summarized Table 1 and the Supporting Information, Table S1, and the

\begin{tabular}{|c|c|c|}
\hline Parameters & $\begin{array}{l}\text { [DPP-ZnP- } \\
\text { GdDOTA] }^{-}\end{array}$ & {$\left[\mathrm{Fe}\left\{\mathrm{Gd}_{2} \mathrm{bpy}(\mathrm{DTTA})_{2}\left(\mathrm{H}_{2} \mathrm{O}\right)_{4}\right\}_{3}\right]^{4-}$} \\
\hline$M_{\mathrm{w}}$ & $2448 \mathrm{Da}$ & $3744 \mathrm{Da}$ \\
\hline $\begin{array}{l}r_{1}\left[\mathrm{mmol} \mathrm{L}^{-1} \mathrm{~s}^{-1} ; 20 \mathrm{MHz},\right. \\
\left.25^{\circ} \mathrm{C}\right]\end{array}$ & 19.94 & 27.03 \\
\hline$q^{[\mathrm{a}]}$ & 1 & 2 \\
\hline$k_{\mathrm{ex}}^{298}\left[10^{6} \mathrm{~s}^{-1}\right]^{[\mathrm{a}]}$ & 4.1 & 7.4 \\
\hline$\Delta H^{\neq}\left[\mathrm{kJ} \mathrm{mol}^{-1}\right]^{[\mathrm{a}]}$ & 49.8 & 41.3 \\
\hline$E_{1}\left[\mathrm{~kJ} \mathrm{~mol}^{-1}\right]$ & $40 \pm 9$ & - \\
\hline$\tau_{1}^{298}[\mathrm{ps}]$ & $245 \pm 27$ & 190 \\
\hline$E_{\mathrm{g}}\left[\mathrm{kJ} \mathrm{mol}{ }^{-1}\right]$ & $14 \pm 5$ & - \\
\hline$\tau_{\mathrm{g}}^{298}[\mathrm{ps}]$ & $2640 \pm 200$ & 930 \\
\hline & $0.26 \pm 0.02$ & 0.6 \\
\hline
\end{tabular}

[a] Fixed during the fitting procedure.

fitted curves are presented in Figure 3 . The parameters characterizing electron spin relaxation $\left(\tau_{\mathrm{v}}=38 \pm 10\right) \mathrm{ps}, \Delta^{2}=(0.34 \pm$ $0.04) \times 10^{19} \mathrm{~s}^{-2}$ ) are poorly determined by this fit and should not be over-interpreted. In Table 1, we compare our data to those reported for a metallostar $\left[\mathrm{Fe}\left\{\mathrm{Gd}_{2} \mathrm{bpy}(\mathrm{DTTA})_{2}\left(\mathrm{H}_{2} \mathrm{O}\right)_{4}\right\}_{3}\right]^{4-}$ compound which is a discrete molecular contrast agent with six Gd"I units conjugated to an iron(II)-tris(byridine) complex. Although the metallostar has a higher molecular weight (3.7 kDa), and a higher hydration number per Gd"' (two instead of one for [DPP-ZnP-GdDOTA] ${ }^{-}$), we chose this comparison since its rotational dynamics has been also described with the model-free Lipari-Szabo formalism. ${ }^{[23]}$

The global and local rotational correlation times obtained for [DPP-ZnP-GdDOTA $]^{-}$are longer than those for the metallos$\operatorname{tar}\left[\mathrm{Fe}\left\{\mathrm{Gd}_{2} \mathrm{bpy}(\mathrm{DTTA})_{2}\left(\mathrm{H}_{2} \mathrm{O}\right)_{4}\right\}_{3}\right]^{4-}$ and are rather similar to the values reported for micellar systems ${ }^{[17 b]}$ (for example, suggesting that the formation of aggregates should be indeed considered to contribute to the high relaxivities). The low value of $S^{2}$ shows that the motion of the Gd"'-coordinated water proton vector is largely decoupled from the overall motion of the aggregates. One contributing factor to this flexibility is the presence of the alkyl-amide linker between the GdDOTA and the highly rigid porphyrin core. As compared to $\left[\mathrm{Fe}\left\{\mathrm{Gd}_{2} \mathrm{bpy}(\mathrm{DTTA})_{2}\left(\mathrm{H}_{2} \mathrm{O}\right)_{4}\right\}_{3}\right]^{4-}$ (Table 1$)$, the relaxivity of our system is lower under similar conditions. This lower relaxivity is related to: 1 ) its lower hydration number (equal to one instead of two for each of the six $\mathrm{Gd}$ centers of $\left.\left\{\mathrm{Fe}\left[\mathrm{Gd}_{2} \mathrm{bpy}(\mathrm{DTTA})_{2}\left(\mathrm{H}_{2} \mathrm{O}\right)_{4}\right]_{3}\right\}^{4-}\right)$, and 2) the increased flexibility of the $\mathrm{Gd}^{\text {III }}$ centers in [DPP-ZnP-GdDOTA] ${ }^{-}$(lower $S^{2}$ value), despite a larger size also reflected in the larger values of the global rotational correlation time, $\tau_{\mathrm{g}}{ }^{298}$ (due to the large molecular weight of [DPP-ZnP-GdDOTA $]^{-}$and its possible aggregation).

Given the hydrophobic nature of the $\pi$-conjugate diketopyrrolopyrrole-zinc(II)porphyrin system, we anticipated a possible interaction of [DPP-ZnP-GdDOTA ${ }^{-}$with serum proteins such as BSA (bovine serum albumin) through hydrophobic interactions. ${ }^{[24]}$ This interaction would result in a longer $\tau_{R}$, so an increased relaxivity, as well as a longer circulation time. At $20 \mathrm{MHz}$ and $25^{\circ} \mathrm{C}$, the addition of the physiological concentration of BSA $\left(38 \mathrm{~g} \mathrm{~L}^{-1}\right)$ yields a relaxivity of $23.94 \mathrm{~mm}^{-1} \mathrm{~s}^{-1}$, that is, a circa $20 \%$ increase in relaxivity compared to the value in $\mathrm{H}_{2} \mathrm{O}$ only $\left(19.94 \mathrm{~mm}^{-1} \mathrm{~s}^{-1}\right)$. This indicates the formation of a supramolecular entity between our system and BSA, although it is difficult to know if BSA interacts with the monomeric or the aggregated form of [DPP-ZnP-GdDOTA $]^{-}$, or both.

\section{Absorption and emission properties: Singlet oxygen produc- tion}

The theranostic system [DPP-ZnP-GdDOTA $]^{-}$was designed for two-photon absorption. However, since the relaxed triplet excited state formed upon two-photon excitation and responsible for the photoreactivity of interest is identical to the one produced by one-photon excitation, we performed a photophysical characterization of the system (absorption, emission, singlet oxygen yield) by a conventional one-photon study. Characteristics such as absorption, and fluorescence quantum yield, are key parameters for the determination of two photon absorption spectra. Moreover, traceability of the photosensitizer inside cells by fluorescence imaging depends on the luminescence efficiency, whereas one- and two-photon phototoxicity induced by singlet oxygen are strictly related to energy transfer from the excited triplet state of the sensitizer to molecular oxygen.

The photophysical characterization of [DPP-ZnP-GdDOTA] was performed in three solvents of different polarity: dichloromethane (DCM), dimethyl sulfoxide (DMSO), and water $\left(\mathrm{H}_{2} \mathrm{O}\right)$.

Absorption spectra obtained in these three solvents are shown in Figure 4. The spectrum in DMSO appears more re-

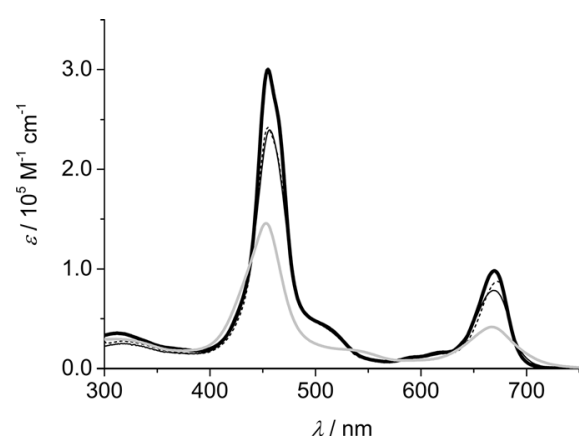

Figure 4. Absorption spectra of [DPP-ZnP-GdDOTA $]^{-}$in DCM (black thin), DCM with $1 \%$ pyridine (black dashed), DMSO (black thick), and $\mathrm{H}_{2} \mathrm{O}$ (gray). 
solved than in the other two solvents; in $\mathrm{H}_{2} \mathrm{O}$, in particular, a marked broadening of all bands occurs, very likely ascribable to aggregation phenomena, as also evidenced by relaxometry (see above). In comparison to the precursor DPP-ZnP-TIPS previously characterized ${ }^{[11]}$ [DPP-ZnP-GdDOTA ${ }^{-}$displays a bathochromic spectral shift that is possibly due to the extended conjugation introduced by the phenyl group, the shift being more pronounced in DCM than in DMSO (Supporting Information, Figure S15).

Emission spectra recorded at room temperature are displayed in Figure 5 and the relevant luminescence data are collected in Table 2. In DCM and DMSO the typical features of porphyrin fluorescence appear, whereas in $\mathrm{H}_{2} \mathrm{O}$ a weak and almost featureless spectrum is observed. In the latter case a very low emission quantum yield and a non-exponential decay, which can be fitted by a bi-exponential function with a good approximation, are observed (Table 2), confirming important aggregation phenomena in this solvent. The fluorescence spectral features of the theranostic system in DCM and DMSO are not affected by the solvent polarity and in both solvents the emission maximum is at ca. $685 \mathrm{~nm}$, overall red-shifted with respect to precursor DPP-ZnP-TIPS. ${ }^{[1]]}$ The emission decays are single exponentials, with a common value of $0.85 \pm$ 0.1 (Table 2).

The emission quantum yield in DCM is about 2.5 times lower than that in DMSO, which is most likely due to moderate aggregation phenomena. To verify this assumption, the characterization in DCM was also performed in presence of $1 \%$ pyridine, which, by axial coordination to the central $Z n^{\text {"l }}$ ion of the porphyrin, inhibits aggregate formation. Both absorption and emission spectral profiles are almost unaffected by the addition of pyridine (Figure 4 and 5), in contrast to the red shift usually observed for Zn-porphyrin axially complexed by N-ligands, whereas the emission quantum yield recovers the value observed in DMSO (0.14, Table 2$)$, similar to the one measured for precursor DPP-ZnP-TIPS in both solvents (0.15).

Singlet oxygen quantum yield determinations were performed by direct measurement of singlet oxygen phosphorescence in DCM and $\mathrm{D}_{2} \mathrm{O}$ and by an indirect method in DMSO. In fact, the poor luminescence properties of singlet oxygen in the latter solvent preclude direct phosphorescence determination. ${ }^{[25]}$ In DCM, $\phi_{\Delta}$ is of the order of 0.24 with almost no dependence on the concentration of the solution (Table 2 and Figure 6). The addition of pyridine increases this value, and

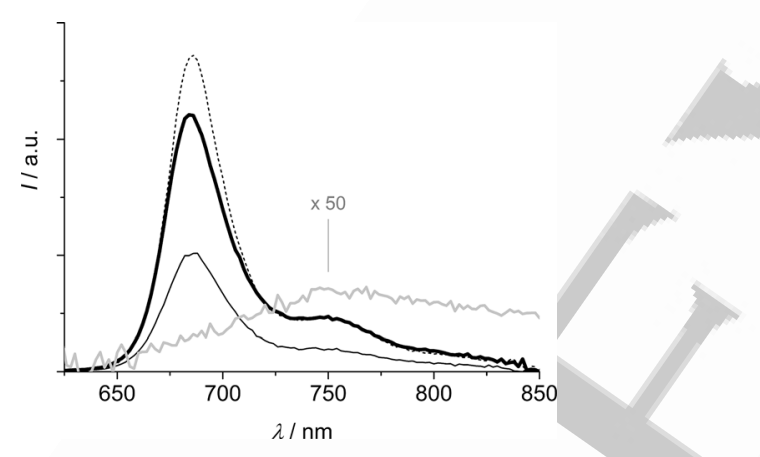

Figure 5. Corrected emission spectra of iso-absorbing solutions of [DPP-ZnPGdDOTA] $^{-}$in DCM (black thin), DCM with $1 \%$ pyridine (black dashed), DMSO (black thick), and $\mathrm{H}_{2} \mathrm{O}$ (gray). The spectrum in $\mathrm{H}_{2} \mathrm{O}$ is multiplied by 50 . Excitation is performed at $514 \mathrm{~nm}\left(A_{514}=0.070\right)$

Table 2. Luminescence data at room temperature. ${ }^{[a]}$

\begin{tabular}{|c|c|c|c|c|c|}
\hline & & $\lambda_{\max }[\mathrm{nm}]^{[\mathrm{b}]}$ & $\phi_{\mathrm{fl}}^{[c]}$ & $\tau[\mathrm{ns}]^{[\mathrm{d}]}$ & $\phi_{\Delta}{ }^{[\mathrm{e}]}$ \\
\hline [DPP-ZnP- & DCM & 686,750 & 0.057 & 0.84 & $0.24 \pm 0.03$ \\
\hline \multirow[t]{5}{*}{$\mathrm{GdDOTA}^{-}$} & & $(686,750)$ & $(0.14)$ & $(0.90)$ & $(0.42 \pm 0.08)$ \\
\hline & DMSO & 684,750 & 0.14 & 0.86 & 0.68 \\
\hline & $\mathrm{H}_{2} \mathrm{O}$ & 762 & $2.2 \times 10^{-3}$ & 0.41 & $--^{[f]}$ \\
\hline & & & & [60\%]; & \\
\hline & & & & 1.10 & \\
\hline \multirow[t]{2}{*}{ DPP-ZnP-TIPS } & DCM & $658,724^{[g]}$ & $0.15^{[\mathrm{g}]}$ & $\begin{array}{l}{[40 \%]} \\
1.06^{[g]}\end{array}$ & $0.58^{[\mathrm{g}]}$ \\
\hline & DMSO & $672,734^{[\mathrm{g}]}$ & $0.15^{[\mathrm{g}]}$ & $1.00^{[\mathrm{g}]}$ & $0.54^{[\mathrm{h}]}$ \\
\hline
\end{tabular}

[a] In round brackets values obtained with $1 \%$ pyridine. [b] From corrected emission spectra. [c] Fluorescence quantum yields, measured with reference to TPP (tetraphenylporphyrin) in aerated toluene as a standard. [d] Fluorescence lifetimes, excitation at $560 \mathrm{~nm}$. [e] Singlet oxygen production quantum yields; see the Experimental Section for details. [f] In $\mathrm{D}_{2} \mathrm{O}$, below detection limit. [g] From Ref. [11]. [h] Measured with an indirect method using DPBF as singlet oxygen trap (unpublished results).
Figure 6. Singlet oxygen production quantum yield of [DPP-ZnP-GdDOTA $]^{-}$ in DCM (•) and in DCM with $1 \%$ pyridine $(\circ)$ as a function of absorbance at $442 \mathrm{~nm}$.

a concentration-dependent behavior is observed (Figure 6). The higher value of singlet oxygen quantum yield (mean value: 0.42 ) can be ascribed to a disaggregation effect induced by pyridine. Nevertheless, this value is also affected by the axial pyridine bond to the central $\mathrm{Zn}$ ion that changes the photophysical parameters of the porphyrin. In $\mathrm{D}_{2} \mathrm{O}$, no singlet oxygen signal was observed from [DPP-ZnP-GdDOTA $]^{-}$, which is most likely due to the aggregation phenomena favoring annihilation processes, lowering the singlet oxygen quantum yield below our experimental detection limit, around 0.1 in these conditions. In DMSO the singlet oxygen quantum yield was determined by using 1,3-diphenylisobenzofuran (DPBF) as a singlet oxygen trap with reference to $Z n$-phthalocyanine $\left(\mathrm{ZnPc}, \phi_{\Delta}=0.67\right)^{[26]}$ (see Experimental Section for details). Figure $7 \mathrm{a}$ shows the evolution of the absorption spectrum of a mixture of [DPP-ZnP-GdDOTA ${ }^{-}$and DPBF upon irradiation at $672 \mathrm{~nm}$. Subtraction of the constant contribution of [DPP-ZnP$\mathrm{GdDOTA}^{-}$, not experiencing photodegradation, allows the vis- 
a)

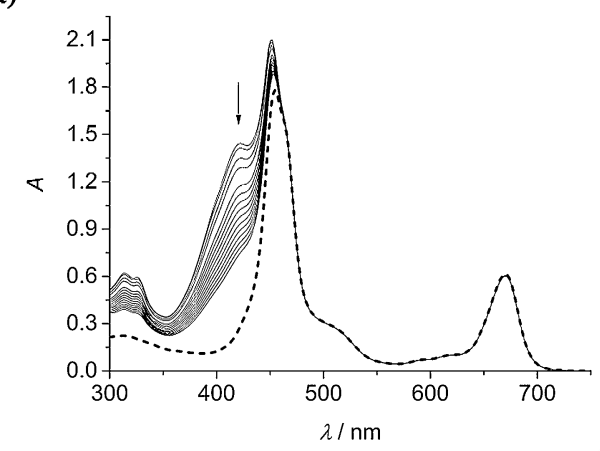

b)

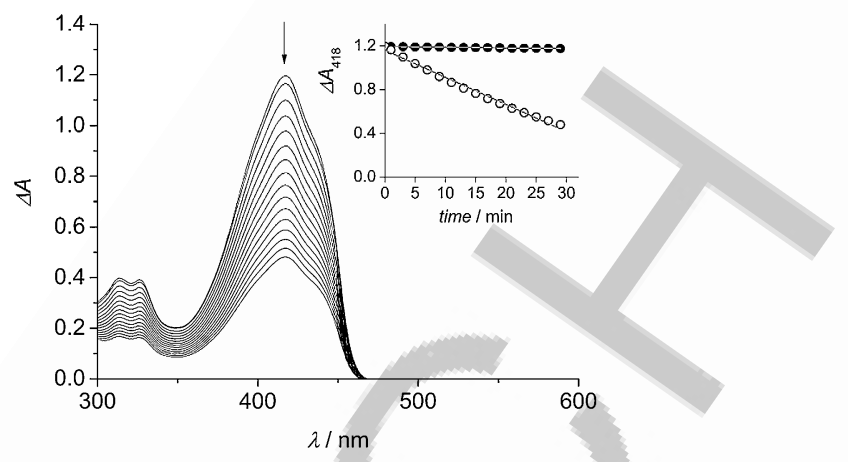

Figure 7. a) Absorption spectra of a DMSO solution containing [DPP-ZnP-GdDOTA $]^{-}\left(7.8 \times 10^{-6} \mathrm{M}_{1}-\mathrm{-}^{--}\right)$and DPBF $\left(5.2 \times 10^{-5} \mathrm{M}\right)$ upon irradiation at $672 \mathrm{~nm}(0-$ $30 \mathrm{~min}$ ). b) The same spectra as (a) subtracted by the contribution of [DPP-ZnP-GdDOTA $]^{-}$. Inset: the value of DPBF absorbance at $418 \mathrm{~nm}$ as a function of irradiation time ( $O$; values for the same experiment in the presence of $\mathrm{NaN}_{3} 5.0 \times 10^{-2} \mathrm{M}$ are shown as $\bullet$ ).

ualization of the consumption of DPBF as a function of the irradiation time (Figure $7 \mathrm{~b}$ ). Addition of $\mathrm{NaN}_{3}$ to the mixture, a known singlet oxygen quencher, leads to invariance of DBPF absorbance under the same irradiation conditions (Figure $7 \mathrm{~b}$ inset). By comparison with the degradation rate measured upon irradiation of the standard ZnPc (Supporting Information, Figure S16 and S17) and taking into consideration the intensity of absorption at the excitation wavelength of both the sample and the standard, the $\phi_{\Delta}$ value for [DPP-ZnP-GdDOTA ${ }^{-}$in DMSO is calculated as 0.68 (Table 2 ). This value is significantly higher than that measured for DPP-ZnP-TIPS in DMSO $\left(\phi_{\Delta}=\right.$ 0.54 , Table 2), showing that the proximity of the $\mathrm{Gd}^{\mathrm{III}}$ complex has a positive role in increasing the intersystem-crossing yield and hence the triplet yield of the photosensitizer.

[DPP-ZnP-GdDOTA $]^{-}$was found to be thermally and photophysically stable in the explored solvents and under the employed experimental conditions.

\section{Two-photon excitation spectra}

TPA properties were investigated by means of the two-photon induced fluorescence method as described previously. ${ }^{[11]}$ TPA was studied in DCM containing $1 \%$ pyridine to avoid aggregation and in DMSO. The low values of [DPP-ZnP-GdDOTA] ${ }^{-}$fluorescence quantum yield in water precluded the determination of $\sigma_{2}$ in this solvent. Figure 8 shows the two-photon excitation spectra of [DPP-ZnP-GdDOTA] ${ }^{-}$in DCM with $1 \%$ pyridine and in DMSO. This agent shows an interesting two-band pattern in the $800-950 \mathrm{~nm}$ range with two maxima, one in the 800$840 \mathrm{~nm}$ range $\left(\sigma_{2} \approx 750 \mathrm{GM}\right)$ and one in the $910-940$ range $\left(\sigma_{2}\right.$ $\approx 1000 \mathrm{GM}$ ). The second band is slightly red-shifted from DCM to DMSO, but the TPA intensity is similar in both solvents. Compared to DPP-ZnP-TIPS, the parent molecule without the contrast agent, $\sigma_{2}$ values in DCM are similar, whereas in DMSO, the values are slightly higher. Combined to high singlet oxygen generation quantum yield, these values yield to interesting two-photon singlet oxygen action cross-section $\sigma_{2} \cdot \phi_{\Delta}$ (in the range $910-940 \mathrm{~nm}$ ) of 680 and $460 \mathrm{GM}$ in DMSO and DCM (1\% pyridine), respectively.

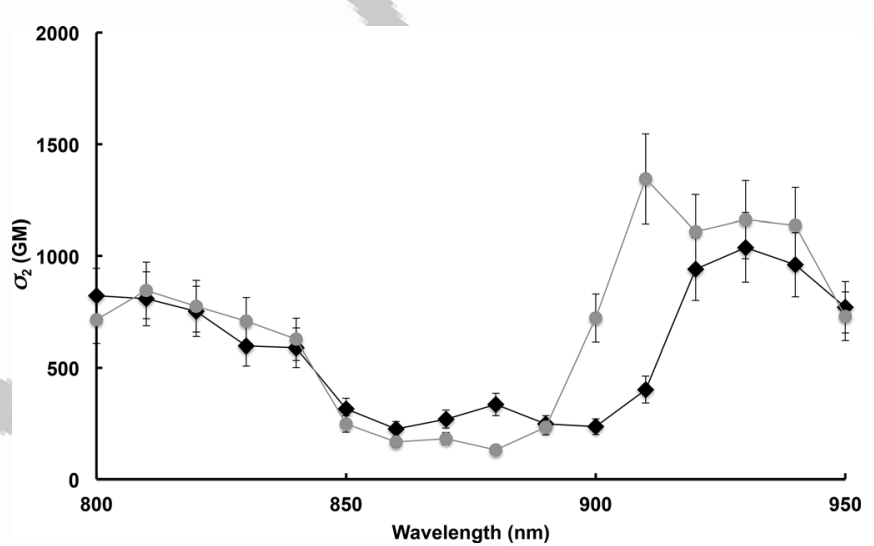

Figure 8. Two-photon excitation spectra of [DPP-ZnP-GdDOTA $]^{-}$in DCM containing $1 \%$ pyridine $(\bullet)$ and in DMSO $(\bullet)$.

\section{Cell behavior}

The cellular penetration of [DPP-ZnP-GdDOTA ${ }^{-}$was studied by confocal microscopy. The presence of the gadolinium complex slows down the cell penetration as compared to DPP-ZnP-TIPS, and the maximum fluorescence signal obtained after incubation of HeLa cells with a $1 \mu \mathrm{m}$ solution of the sensitizer was detected after $24 \mathrm{~h}$ instead of $2 \mathrm{~h}$. After $24 \mathrm{~h}$ incubation, twophoton excited images (Figure 9) were also registered. The brightness of this system in cells is lower than the one of the parent molecule, indeed the laser power used to acquire contrasted images was higher than for DPP-ZnP-TIPS both in confocal and two-photon excited microscopy.

The dark cytotoxicity of [DPP-ZnP-GdDOTA $]^{-}$was studied by MTT (3-(4,5-dimethylthiazol-2-yl)-2,5-diphenyl tetrazolium bromide) test. A moderate dark toxicity was detected below $2 \mu \mathrm{M}$ after $28 \mathrm{~h}$ incubation with the sensitizer (Figure 10).

\section{One-photon phototoxicity}

Phototoxicity of [DPP-ZnP-GdDOTA $]^{-}$was investigated using a homemade LED Irradiation apparatus as described by Anderson et al. ${ }^{[6]]}$ After $24 \mathrm{~h}$ incubation with $1 \mu \mathrm{M}$ [DPP-ZnPGdDOTA] $^{-}$in DMEM containing $1 \%$ DMSO, the cells were irra- 


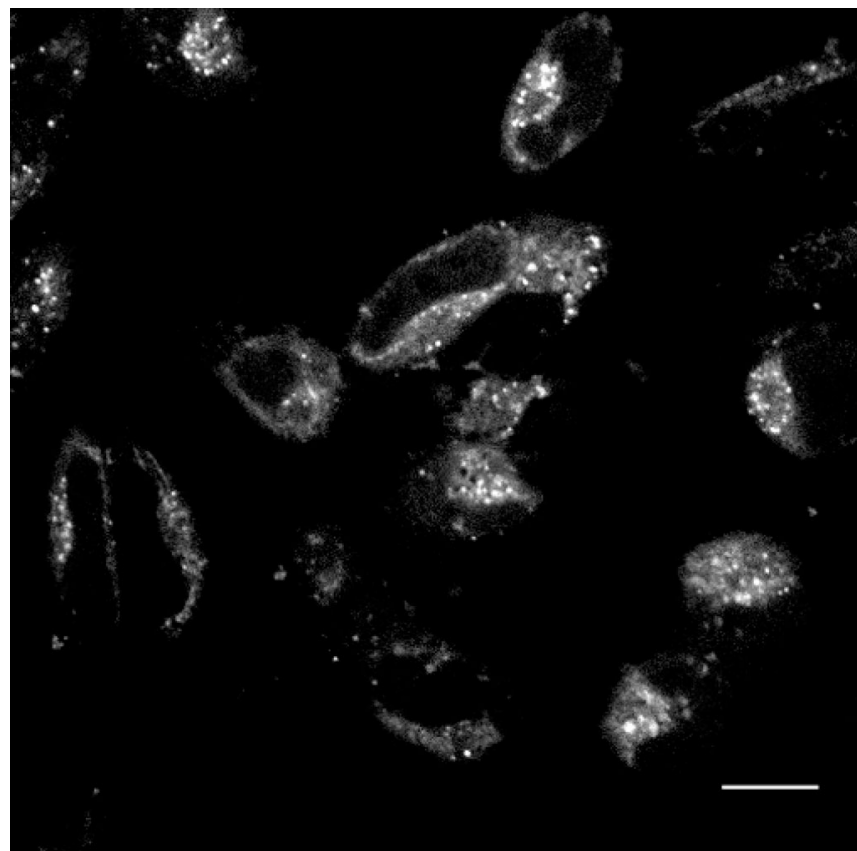

Figure 9. Two-photon excited microscopy image of HeLa cells incubated with $1 \mu \mathrm{M}$ of [DPP-ZnP-GdDOTA] ${ }^{-}$for $24 \mathrm{~h}\left(\lambda_{\mathrm{ex}}=920 \mathrm{~nm}\right.$, laser pow$\mathrm{er}=10 \mathrm{~mW}$, scale bar $=25 \mu \mathrm{m})$.

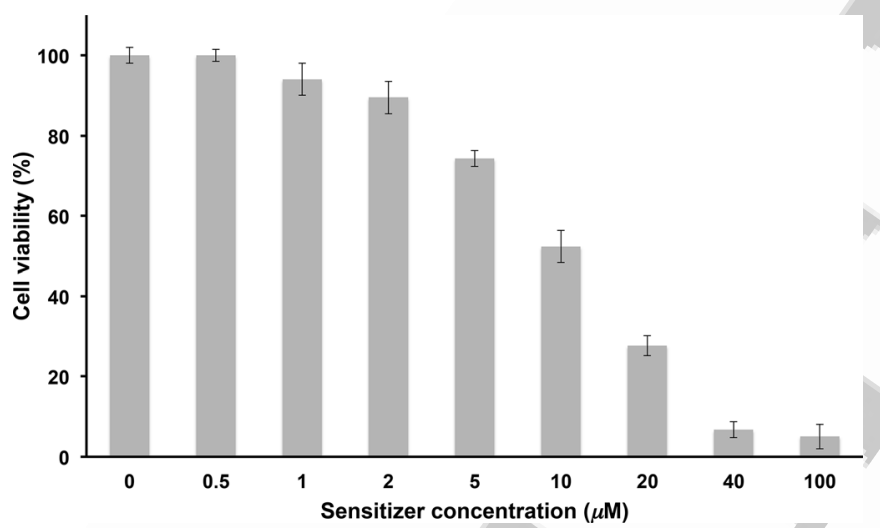

Figure 10. Evaluation of the cytotoxicity of [DPP-ZnP-GdDOTA $]^{-}$after $28 \mathrm{~h}$ incubation on HeLa cell cultures.

diated one hour $\left(\lambda_{\text {ex }}=660 \mathrm{~nm}, \mathrm{P}=1.7-4.2 \mathrm{~mW} / \mathrm{cm}^{2}\right)$. The cell viability was assessed $5 \mathrm{~h}$ after irradiation using the MTT assay (Figure 11).

Non-irradiated cells showed a similar toxicity to the one observed for the dark toxicity test. After one-hour irradiation with an irradiance of $4.2 \mathrm{~mW} / \mathrm{cm}^{2}, 70 \%$ of cell death was detected, even with a low concentration of the sensitizer $(1 \mu \mathrm{M}$, compared to $10 \mu \mathrm{M}$ classically used). Irradiations with different powers allowed us to determine the $\mathrm{LD}_{50}$ (light dose) of [DPPZnP-GdDOTA $]^{-}$, which was equal to $9 \mathrm{~J} \mathrm{~cm}^{-2}$.

\section{Two-photon phototoxicity}

Preliminary two-photon induced cell phototoxicity behavior was explored with $1 \mu \mathrm{M}$ [DPP-ZnP-GdDOTA $]^{-}$as described pre-

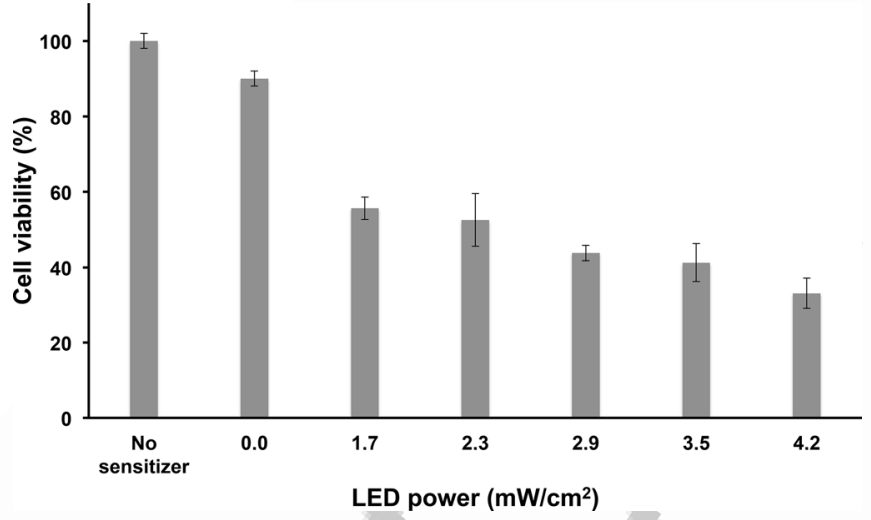

Figure 11. One-photon phototoxicity assay on HeLa cells of [DPP-ZnP$\mathrm{GdDOTA}^{-}$at $1 \mu \mathrm{M}$ concentration after one hour of irradiation at $\lambda_{\text {ex }}=660 \mathrm{~nm}$.

viously. ${ }^{[10 a-e]}$ Briefly, $250 \times 250 \mu \mathrm{m}$ area of a HeLa cell culture was incubated $24 \mathrm{~h}$ with [DPP-ZnP-GdDOTA $]^{-}$and then irradiated under a TP microscope $\left(\lambda_{\mathrm{ex}}=930 \mathrm{~nm}, P=8 \mathrm{~mW}, 300\right.$ scans at $400 \mathrm{~Hz}$, pixel dwell time of $1.4 \mu \mathrm{s})$. The cell viability was assessed $4 \mathrm{~h}$ after irradiation by means of a double coloration with Hoechst (all cells staining) and Cytox orange (compromised membrane cells) nuclear stains. The irradiation led to about $50 \%$ of cell death, whereas the irradiation of a similar cell area not incubated with the sensitizer did not induce significant cell death (2-5\% of dead cells). Since non-irradiated zones presented an average cell death of $20 \%$, consistent with the dark toxicity measured with the MTT test, a moderate twophoton phototoxicity of $30 \%$ can be inferred (Supporting Information, Figure S18 and S19).

\section{Conclusion}

A potential theranostic molecule that associates for the first time a two-photon photosensitizer for PDT with a GdDOTAbased MRI contrast agent was synthesized. The new conjugate [DPP-ZnP-GdDOTA] $]^{-}$and the $\mathrm{Y}^{\text {III-}}$-complexed analogue [DPPZnP-YDOTA $]^{-}$were obtained in good yield, high purity and were fully characterized. [DPP-ZnP-GdDOTA $]^{-}$exhibits a high longitudinal water proton relaxivity, $r_{1}$ of $19.94 \mathrm{~mm}^{-1} \mathrm{~s}^{-1}$ at $20 \mathrm{MHz}, 25^{\circ} \mathrm{C}$ in water and this value is further increased to $23.94 \mathrm{~mm}^{-1} \mathrm{~s}^{-1}$ in the presence of BSA, demonstrating its potential as an efficient contrast agent for in vivo MRI applications. The new molecule has a high two-photon cross section around 1000 GM in DCM (1\% pyridine) and DMSO in the 910$940 \mathrm{~nm}$ range, corresponding to the therapeutic window. The singlet oxygen generation is high in DMSO and more limited in DCM, where aggregation phenomena occur. Concerning biological applications, the molecule is robust, penetrates in cells and presents low dark toxicity. Preliminary PDT experiments on HeLa cancer cells are promising; the conjugate demonstrates high one-photon and moderate two-photon phototoxicity. Finally, the present system also validates the concept of using a therapeutic agent, here the diketopyrrolopyrrolezinc(II)porphyrin conjugate, as a vector to convey an imaging 
probe of high relaxivity inside cells, in contrast to extracellular agents of clinical use, such as GdDOTA. Such theranostic agents are promising to expand MRI towards novel molecular imaging applications and to perform more efficient PDT treatments.

\section{Experimental Section}

\section{General information}

All chemicals were of the best commercially available grade and used without further purification. Tetrahydrofuran was dried using a dry solvent station GT S100. Dry chloroform was obtained by distillation over $\mathrm{CaH}_{2}$ under nitrogen. Triethylamine $\left(\mathrm{Et}_{3} \mathrm{~N}, 99 \%\right)$, and anhydrous dimethyl sulfoxide (DMSO, 99.7\%) were purchased from Aldrich Chemicals (France). Analytical thin-layer chromatography (TLC) was carried out on Merck aluminum backed silica gel 60 F254 plates and visualization when required was achieved using UV light. Precoated plates (PLC Silica gel $60 \mathrm{~F}_{254}, 2 \mathrm{~mm}$ ) were used for preparative thin-layer chromatography. Column chromatography was carried out on silica (Fluka 60, 70-230 mesh). Size-exclusion chromatography was carried out using Bio-Beads S-X1, 200400 mesh (Bio-Rad). NMR spectra were recorded at the ambient probe temperature using Bruker AVANCE 300, 400 or 500 spectrometers. Chemical shifts are quoted as parts per million (ppm) relative to the residual peak of solvent and coupling constants $(J)$ are quoted in Hertz $(\mathrm{Hz})$. Where assignments of ${ }^{1} \mathrm{H}$ NMR spectra are given, they were unambiguously established via COSY, HSQC, HMBC and ROESY experiments. In the assignments, the chemical shift (in ppm) is given first, followed, in brackets, by the multiplicity of the signal (s singlet, $\mathrm{d}$ doublet, $\mathrm{t}$ triplet, $\mathrm{m}$ multiplet, br $\mathrm{s}$ broad signal), the number of protons implied, the value of the coupling constants in Hertz if applicable, and finally the assignment. UV/Vis spectra were recorded on a UVIKON XL spectrophotometer. Mass spectra were obtained by using a Bruker MicroTOF spectrometer (ES-MS). ICP-AES was performed by emission spectrometry with a Vista AX CCD Simultaneous ICP-AES Varian spectrophotometer.

Compounds tert-butoxycarbonyl (Boc)-protected 3-iodobenzylamine (I-Ph-NHBoc), ${ }^{[13]} \mathrm{Na}_{2}\left[\right.$ GdDOTAGA,${ }^{[12]}$ and $\mathrm{Na}_{2}\left[\right.$ YDOTAGA] ${ }^{[12]}$ were prepared according to previous reports.

\section{Synthesis of DPP-ZnP-NHBoc}

A solution of TBAF $(25 \mathrm{mg}, 79 \mu \mathrm{mol})$ in dry THF $(1 \mathrm{~mL})$ was added to a degassed solution of DPP-ZnP-TIPS $(147 \mathrm{mg}, 79 \mu \mathrm{mol})$ in dry THF ( $24 \mathrm{~mL}$ ) under argon. The reaction mixture was stirred at room temperature for $20 \mathrm{~min}$ and then anhydrous calcium chloride ( $87 \mathrm{mg}, 0.786 \mathrm{mmol}$ ) was added. The solvent was evaporated and the crude was submitted to a silica gel column chromatography (DCM/MeOH 96:4). Due to its instability, the deprotected compound DPP-ZnP-H obtained as a brown-green solid was rapidly used for the next reaction.

DPP-ZnP-H $(65 \mathrm{mg}, 20 \mu \mathrm{mol}),\left[\mathrm{Pd}_{2}(\mathrm{dba})_{3}\right](1.7 \mathrm{mg}, 2 \mu \mathrm{mol}), \mathrm{Cul}$ (0.5 mg, $2.7 \mu \mathrm{mol}), \mathrm{PPh}_{3}(2.5 \mathrm{mg}, 9.5 \mu \mathrm{mol})$, and I-Ph-NHBoc (19 mg, $57 \mu \mathrm{mol}$ ) were dried under vacuum for 1 hour at $45^{\circ} \mathrm{C}$. A solution of dry THF $(2 \mathrm{~mL})$ and $\mathrm{Et}_{3} \mathrm{~N}(1 \mathrm{~mL})$ degassed by four freeze-thaw cycles was transferred by cannula to the solids placed under argon. The resulting mixture was stirred at $50^{\circ} \mathrm{C}$ for $2 \mathrm{~h}$. The solvents were evaporated and the product was purified by silica gel column chromatography (DCM/pyridine $1 \% / \mathrm{MeOH} 1$ to $2 \%$ ) followed by size-exclusion column chromatography (Bio-Beads S-X1) with DCM. DPP-ZnP-NHBoc was obtained as a brown-green solid in $42 \%$ yield $(63 \mathrm{mg})$.
${ }^{1} \mathrm{H}$ NMR $\left(300 \mathrm{MHz}, \mathrm{CDCl}_{3}+1 \%\right.$ pyridine, $\left.298 \mathrm{~K}\right): \delta=1.50(\mathrm{~s}, 9 \mathrm{H}$, $\left.\mathrm{H}_{10}\right), 3.30\left(\mathrm{~s}, 12 \mathrm{H}, \mathrm{H}_{1}\right), 3.33\left(\mathrm{~s}, 3 \mathrm{H}, \mathrm{H}_{25}\right), 3.39\left(\mathrm{~s}, 3 \mathrm{H}, \mathrm{H}_{20}\right), 3.44-3.50$ $\left(\mathrm{m}, 10 \mathrm{H}, \mathrm{H}_{24}, \mathrm{H}_{2}\right), 3.55-3.57\left(\mathrm{~m}, 4 \mathrm{H}, \mathrm{H}_{23}, \mathrm{H}_{19}\right), 3.60-3.63\left(\mathrm{~m}, 10 \mathrm{H}, \mathrm{H}_{3}\right.$, $\left.\mathrm{H}_{18}\right), 3.66-3.70\left(\mathrm{~m}, 8 \mathrm{H}, \mathrm{H}_{4}\right), 3.74-3.79\left(\mathrm{~m}, 10 \mathrm{H}, \mathrm{H}_{22}, \mathrm{H}_{5}\right), 3.82-3.85$ $\left(\mathrm{m}, 2 \mathrm{H}, \mathrm{H}_{17}\right), 3.92-3.95\left(\mathrm{~m}, 8 \mathrm{H}, \mathrm{H}_{6}\right), 3.98-4.02\left(\mathrm{~m}, 2 \mathrm{H}, \mathrm{H}_{21}\right), 4.04-$ $4.08\left(\mathrm{~m}, 2 \mathrm{H}, \mathrm{H}_{16}\right), 4.29-4.33\left(\mathrm{~m}, 8 \mathrm{H}, \mathrm{H}_{7}\right), 4.42\left(\mathrm{~d}, J=5.5 \mathrm{~Hz}, 2 \mathrm{H}, \mathrm{H}_{8}\right)$, $5.20\left(\mathrm{br} \mathrm{s}, 1 \mathrm{H}, \mathrm{H}_{9}\right), 6.93(\mathrm{t}, J=2.1 \mathrm{~Hz}, 2 \mathrm{H}, \mathrm{p}), 7.36(\mathrm{~d}, J=2.2 \mathrm{~Hz}, 4 \mathrm{H}$, o), $7.45\left(\mathrm{~d}, J=8.2 \mathrm{~Hz}, 2 \mathrm{H}, \mathrm{o}^{\prime \prime}\right), 7.51-7.53(\mathrm{~m}, 3 \mathrm{H}, \mathrm{mp}, \mathrm{pp}), 7.96(\mathrm{~d}$, $\left.J=8.3 \mathrm{~Hz}, 2 \mathrm{H}, \mathrm{m}^{\prime \prime}\right), 7.98-8.01(\mathrm{~m}, 2 \mathrm{H}, \mathrm{op}), 8.13(\mathrm{~d}, J=8.5 \mathrm{~Hz}, 2 \mathrm{H}$, $\left.\mathrm{o}^{\prime}\right), 8.23\left(\mathrm{~d}, J=8.4 \mathrm{~Hz}, 2 \mathrm{H}, \mathrm{m}^{\prime}\right), 8.91\left(\mathrm{~d}, J=4.6 \mathrm{~Hz}, 2 \mathrm{H}, \mathrm{py}_{2}\right.$ or $\left.\mathrm{py}_{3}\right)$, $8.94\left(\mathrm{~d}, J=4.6 \mathrm{~Hz}, 2 \mathrm{H}, \mathrm{py}_{2}\right.$ or $\left.\mathrm{py}_{3}\right), 9.66\left(\mathrm{~d}, J=4.6 \mathrm{~Hz}, 2 \mathrm{H}, \mathrm{py}_{1}\right.$ or $\left.\mathrm{py}_{4}\right), 9.67 \mathrm{ppm}\left(\mathrm{d}, J=4.6 \mathrm{~Hz}, 2 \mathrm{H}, \mathrm{py}_{1}\right.$ or $\left.\mathrm{py}_{4}\right)$.

${ }^{13} \mathrm{C}$ NMR $\left(125 \mathrm{MHz}, \mathrm{CDCl}_{3}+1 \%\right.$ pyridine, $\left.298 \mathrm{~K}\right): \delta=28.53,42.12$, 42.48, 59.04, 59.11, 59.20, 67.89, 68.97, 69.13, 69.92, 70.54, 70.63, $70.74,70.95,71.91,71.97,93.39,96.07,96.23,96.71,100.09,101.07$, $101.45,109.90,110.15,114.88,122.47,123.31,127.36,127.45$, $127.82,128.10,128.89,129.42,129.74,130.56,130.80,131.28$, $131.73,131.83,132.55,132.75,139.51,144.54,148.41,149.29$, $149.82,149.93,152.04,152.21,157.09,157.94,163.03,163.13$ ppm. HR ES-MS: $m / z$ (\%) 981.8761 (100) $[\mathrm{M}+2 \mathrm{Na}]^{2+} / 2$ (calcd 981.8799 for $\left.\left[\mathrm{C}_{104} \mathrm{H}_{121} \mathrm{~N}_{7} \mathrm{O}_{24} \mathrm{ZnNa}_{2}\right]^{2+} / 2\right)$.

\section{Synthesis of DPP-ZnP-NH}

Compound DPP-ZnP-NHBoc ( $63 \mathrm{mg}, 33 \mu \mathrm{mol}$ ) was dissolved in dry $\mathrm{DCM}(7 \mathrm{~mL})$. The resulting mixture was cooled to $0^{\circ} \mathrm{C}$ before $\mathrm{CF}_{3} \mathrm{COOH}(0.5 \mathrm{~mL})$ was added dropwise. After $2 \mathrm{~h}$ at room temperature, the organic layer was washed with water $(7 \mathrm{~mL})$ and aqueous saturated $\mathrm{NaHCO}_{3}(10 \mathrm{~mL})$. The organic layer was dried over $\mathrm{Na}_{2} \mathrm{SO}_{4}$, filtered and evaporated. The crude product was dissolved in dry $\mathrm{CHCl}_{3}(20 \mathrm{~mL})$ and a solution of $\mathrm{Zn}(\mathrm{OAC})_{2} \cdot 2 \mathrm{H}_{2} \mathrm{O}(11 \mathrm{mg}$, $49 \mu \mathrm{mol})$ in $\mathrm{MeOH}(2 \mathrm{~mL})$ was added dropwise. The resulting mixture was stirred at $50^{\circ} \mathrm{C}$ for $3 \mathrm{~h}$. The solvents were evaporated. DCM $(10 \mathrm{~mL})$ was added and the solution was washed twice with brine $(2 \times 10 \mathrm{~mL})$ then with water $(10 \mathrm{~mL})$. The organic layer was dried over $\mathrm{Na}_{2} \mathrm{SO}_{4}$, filtered and evaporated to dryness. DPP-ZnP$\mathrm{NH}_{2}$ was obtained as a brown-green solid in $99 \%$ yield (59 mg).

UV/Vis $(D C M): \lambda_{\max }(\log \varepsilon)=458$ (5.26), $514 \mathrm{sh}, 592 \mathrm{sh}, 683 \mathrm{~nm}$ (4.88).

${ }^{1} \mathrm{H}$ NMR $\left(500 \mathrm{MHz}, \mathrm{CDCl}_{3}+1 \%\right.$ pyridine, $\left.298 \mathrm{~K}\right): \delta=3.30(\mathrm{~s}, 12 \mathrm{H}$, $\left.\mathrm{H}_{1}\right), 3.33\left(\mathrm{~s}, 3 \mathrm{H}, \mathrm{H}_{25}\right), 3.39\left(\mathrm{~s}, 3 \mathrm{H}, \mathrm{H}_{20}\right), 3.45-3.49\left(\mathrm{~m}, 10 \mathrm{H}, \mathrm{H}_{2}, \mathrm{H}_{24}\right)$, 3.51-3.53 (m, 2H, $\left.\mathrm{H}_{19}\right), 3.54-3.56\left(\mathrm{~m}, 2 \mathrm{H}, \mathrm{H}_{23}\right), 3.59-3.62(\mathrm{~m}, 10 \mathrm{H}$, $\left.\mathrm{H}_{18}, \mathrm{H}_{3}\right), 3.67-3.69\left(\mathrm{~m}, 8 \mathrm{H}, \mathrm{H}_{4}\right), 3.76-3.78\left(\mathrm{~m}, 12 \mathrm{H}, \mathrm{H}_{8}, \mathrm{H}_{5}, \mathrm{H}_{22}\right), 3.82-$ $3.85\left(\mathrm{~m}, 2 \mathrm{H}, \mathrm{H}_{17}\right), 3.92-3.94\left(\mathrm{~m}, 8 \mathrm{H}, \mathrm{H}_{6}\right), 3.99-4.01\left(\mathrm{~m}, 2 \mathrm{H}, \mathrm{H}_{21}\right)$, 4.05-4.07 (m, 2H, $\left.\mathrm{H}_{16}\right), 4.30-4.32\left(\mathrm{~m}, 8 \mathrm{H}, \mathrm{H}_{7}\right), 6.93$ (br s, 2H, p), 7.36-7.38 (m, 6H, o, m"), 7.50-7.53 (m, 3H, mp, pp), $7.94(\mathrm{~d}, J=$ $\left.7.9 \mathrm{~Hz}, 2 \mathrm{H}, \mathrm{o}^{\prime \prime}\right), 7.99-8.00(\mathrm{~m}, 2 \mathrm{H}, \mathrm{op}), 8.13\left(\mathrm{~d}, J=8.2 \mathrm{~Hz}, 2 \mathrm{H}, \mathrm{o}^{\prime}\right)$, $8.23\left(\mathrm{~d}, J=8.2 \mathrm{~Hz}, 2 \mathrm{H}, \mathrm{m}^{\prime}\right), 8.91\left(\mathrm{~d}, J=4.4 \mathrm{~Hz}, 2 \mathrm{H}, \mathrm{py}_{2}\right.$ or $\left.\mathrm{py}_{3}\right), 8.94$ $\left(\mathrm{d}, J=4.4 \mathrm{~Hz}, 2 \mathrm{H}, \mathrm{py}_{2}\right.$ or $\left.\mathrm{py}_{3}\right), 9.66\left(\mathrm{~d}, J=4.4 \mathrm{~Hz}, 2 \mathrm{H}, \mathrm{py}_{1} \text { or } \mathrm{py}_{4}\right)_{\text {, }}$ $9.67 \mathrm{ppm}\left(\mathrm{d}, J=4.4 \mathrm{~Hz}, 2 \mathrm{H}, \mathrm{py}_{1}\right.$ or $\left.\mathrm{py}_{4}\right)$.

${ }^{13} \mathrm{C}$ NMR $\left(125 \mathrm{MHz}, \mathrm{CDCl}_{3}+1 \%\right.$ pyridine, $\left.298 \mathrm{~K}\right): \delta=42.08,42.44$, $46.12,59.06,59.13,59.23,67.81,68.93,69.10,69.90,70.51,70.60$, $70.71,70.92,71.88,71.93,93.14,96.00,96.34,96.71,100.00,100.95$, $101.56,109.84,110.09,114.78,122.42,122.77,123.47,127.34$, $127.40,128.03,128.89,129.41,129.73,130.53,130.80,131.29$, $131.73,131.77,132.51,132.74,143.07,144.52,148.42,149.29$, $149.48,149.76,149.87,152.00,152.18,157.88,163.02,163.13$ ppm. HR ES-MS: $m / z$ (\%) $1818.7247(100)[M+H]^{+}$(calcd 1818.7323 for $\left[\mathrm{C}_{99} \mathrm{H}_{114} \mathrm{~N}_{7} \mathrm{O}_{22} \mathrm{Zn}\right]^{+}$). 


\section{Synthesis of $\mathrm{Na}$ [DPP-ZnP-MDOTA]}

A solution of $\mathrm{Na}_{2}$ [MDOTAGA] (12.7 mmol. $\mathrm{L}^{-1}, 50 \mu \mathrm{mol}, 1.5$ equiv) in dry DMSO was stirred under argon at $60^{\circ} \mathrm{C}$ for $5 \mathrm{~h}$. TBTU $(18 \mathrm{mg}$, $56 \mu \mathrm{mol})$ and DIPEA $(18 \mu \mathrm{L}, 102 \mu \mathrm{mol})$ were added to the resulting solution. Then DPP-ZnP-NH 2 (59 mg, $33 \mu \mathrm{mol})$ previously dissolved in dry DMSO $(2 \mathrm{~mL})$ was added dropwise. The reaction mixture was stirred at room temperature overnight. DMSO was evaporated at $60^{\circ} \mathrm{C}$ under reduced pressure before water $(10 \mathrm{~mL})$ and $\mathrm{DCM}$ $(10 \mathrm{~mL})$ were added. The organic layer was washed with water and brine. The organic layer was dried over $\mathrm{Na}_{2} \mathrm{SO}_{4}$, filtered, and evaporated. The product was purified by size-exclusion column chromatography (Bio-Beads S-X1,18 g) eluted with DCM, followed by a silica prep-TLC (2 mm) eluted with $\mathrm{DCM} / \mathrm{MeOH} / \mathrm{NH}_{4} \mathrm{OH}(80: 15: 5)$. The product was extracted from silica three times with a mixture of solvents $\mathrm{DCM} / \mathrm{MeOH} / \mathrm{NH}_{4} \mathrm{OH} / \mathrm{DMSO}$ (80:15:4:1). Remaining silica was removed by several centrifugations and filtrations. After evaporation of the solvents, the compound was redissolved in DCM $(10 \mathrm{~mL})$ and this solution was washed with water $(10 \mathrm{~mL})$ and brine $(10 \mathrm{~mL})$. The organic layer was dried over $\mathrm{Na}_{2} \mathrm{SO}_{4}$, filtered, and evaporated. The compound was dried under vacuum.

Characterization of the gadolinium(III) complex $\mathrm{Na}$ [DPP-ZnPGdDOTA]: Brown-yellow solid (42 mg, 52\%).

UV/Vis: (DCM): $\lambda_{\max }(\log \varepsilon)=455$ (5.29), 515 sh, $590 \mathrm{sh}, 622 \mathrm{sh}$, $672 \mathrm{~nm}$ (4.85).

HR ES-MS: $m / z \quad(\%) \quad 2475.8193 \quad(100) \quad\left[M-\mathrm{H}_{2} \mathrm{O}+2 \mathrm{Na}\right]^{+}$(calcd 2475.7982 for $\left.\left[\mathrm{C}_{118} \mathrm{H}_{139} \mathrm{GdN}_{11} \mathrm{O}_{31} \mathrm{ZnNa}_{2}\right]^{+}, 100 \%\right)$

Characterization of the yttrium(III) complex Na[DPP-ZnP-YDOTA]: Brown-yellow solid.

${ }^{1} \mathrm{H}$ NMR (300 MHz, DMSO, $\left.298 \mathrm{~K}\right): \delta=1.71-1.92\left(\mathrm{~m}, 2 \mathrm{H}, \mathrm{H}_{10}\right), 2.11-$ $2.92(\mathrm{~m}, 25 \mathrm{H}$, DOTA $), 3.19\left(\mathrm{~s}, 12 \mathrm{H}, \mathrm{H}_{1}\right), 3.20\left(\mathrm{~s}, 3 \mathrm{H}, \mathrm{H}_{25}\right), 3.25(\mathrm{~s}, 3 \mathrm{H}$, $\left.\mathrm{H}_{20}\right), 3.38-3.66\left(\mathrm{~m}, 44 \mathrm{H}, \mathrm{OCH}_{2}\right), 3.85\left(\mathrm{~m}, 8 \mathrm{H}, \mathrm{H}_{6}\right), 3.92\left(\mathrm{~m}, 2 \mathrm{H}, \mathrm{H}_{21}\right)$, $3.99\left(m, 2 \mathrm{H}, \mathrm{H}_{16}\right), 4.34\left(\mathrm{~m}, 8 \mathrm{H}, \mathrm{H}_{7}\right), 4.35-4.49\left(\mathrm{~m}, 2 \mathrm{H}, \mathrm{H}_{8}\right), 7.04(\mathrm{~m}$, $2 \mathrm{H}, \mathrm{p}), 7.35$ (br s, $4 \mathrm{H}, \mathrm{o}), 7.51\left(\mathrm{~d}, 2 \mathrm{H}, J=8.1 \mathrm{~Hz}, \mathrm{~m}^{\prime \prime}\right), 7.62(\mathrm{~m}, 3 \mathrm{H}$, $\mathrm{mp}, \mathrm{pp}), 7.97(\mathrm{~m}, 2 \mathrm{H}, \mathrm{op}), 8.09\left(\mathrm{~d}, J=8.1 \mathrm{~Hz}, 2 \mathrm{H}, \mathrm{o}^{\prime \prime}\right), 8.22(\mathrm{~d}, J=$ $\left.8.1 \mathrm{~Hz}, 2 \mathrm{H}, \mathrm{o}^{\prime}\right), 8.31\left(\mathrm{~d}, J=8.1 \mathrm{~Hz}, 2 \mathrm{H}, \mathrm{m}^{\prime}\right), 8.53(\mathrm{br} \mathrm{s}, J=6.5 \mathrm{~Hz}, 1 \mathrm{H}$, $\left.\mathrm{H}_{9}\right), 8.91(\mathrm{~d}, J=4.7 \mathrm{~Hz}, 2 \mathrm{H}$, py2 or py3), $8.93(\mathrm{~d}, J=4.7 \mathrm{~Hz}, 2 \mathrm{H}$, py 2 or py3), $9.71(\mathrm{~d}, J=4.5 \mathrm{~Hz}, 2 \mathrm{H}$, py1 or py4), $9.76 \mathrm{ppm}(\mathrm{d}, J=4.5 \mathrm{~Hz}$, $2 \mathrm{H}$, py1 or py4).

HR ES-MS: $m / z 2406.7977\left[\mathrm{M}-\mathrm{H}_{2} \mathrm{O}+2 \mathrm{Na}\right]^{+}$(calcd 2406.7806 for $\left.\left[\mathrm{C}_{118} \mathrm{H}_{139} \mathrm{YN}_{11} \mathrm{O}_{31} \mathrm{ZnNa}_{2}\right]^{+}, 100 \%\right)$

\section{Spectroscopy and photophysics}

DCM and DMSO were of spectroscopic grade from Merck and Carlo Erba, respectively. Tri-distilled (Millipore Milli-Q) water and deuterated water $\left(D_{2} O\right)$ from VWR Chemicals were used. 1,3-diphenylisobenzofuran (DPBF), Zn-phthalocyanine $(\mathrm{ZnPc})$, pyridine, and sodium azide $\left(\mathrm{NaN}_{3}\right)$ were from Aldrich.

Absorption spectra were recorded with a PerkinElmer Lambda 650 UV/Vis and with a Lambda 9 UV/Vis-NIR spectrophotometers. Emission spectra were collected with an Edinburgh FLS920 fluorimeter equipped with a Peltier-cooled Hamamatsu R928 PMT (200$850 \mathrm{~nm}$ ), and corrected for the wavelength dependent phototube response. The fluorescence quantum yields were determined with reference to TPP (tetraphenylporphyrin) in aerated toluene as a standard $\left.\phi_{\mathrm{fl}}=0.11\right) .{ }^{[27]}$ Fluorescence lifetimes were measured with an IBH time-correlated single photon counting apparatus with excitation both at $465 \mathrm{~nm}$ and $560 \mathrm{~nm}$. The analysis of the luminescence decay profiles against time was accomplished with the DAS6 Decay Analysis Software provided by the manufacturer. Estimated errors are $10 \%$ on exponential lifetimes, $20 \%$ on quantum yields,
$20 \%$ on molar absorption coefficients and $3 \mathrm{~nm}$ on emission and absorption peaks.

Singlet oxygen production quantum yields in $\mathrm{DCM}$ and $\mathrm{D}_{2} \mathrm{O}$ were measured with reference to Rose Bengal bis(triethylammonium)salt $\phi_{\Delta}=0.48$ in $\mathrm{DCM}$ ), ${ }^{[28]}$ and to $5,10,15,20$-tetrakis(4-sulphonatophenyl)porphyrin $\left(\mathrm{TPPS}_{4}\right)\left(\phi_{\Delta}=0.64\right.$ in $\left.\mathrm{D}_{2} \mathrm{O}\right){ }^{\left[{ }^{[29]}\right.}$ respectively, by comparing the intensity of singlet oxygen phosphorescence spectra measured with a FLS920 spectrofluorimeter (Edinburgh) equipped with a Hamamatsu R5509-72 supercooled photomultiplier tube at $193 \mathrm{~K}$ and a TM300 emission monochromator with a grating blazed at $1000 \mathrm{~nm}$. Excitation at $442 \mathrm{~nm}$ was performed with a Kimmon Koha Co., Ltd. HeCd laser (the power was reduced to ca. $7 \mathrm{~mW}$ to avoid annihilation effects).

Singlet oxygen production quantum yield in DMSO was measured with a comparative method using DPBF as a singlet oxygen trap, which is oxidized by singlet oxygen and its degradation can be monitored by the decrease of its absorbance at $418 \mathrm{~nm}^{[30]} \mathrm{ZnPc}$ was used as a standard $\left(\phi_{\Delta}=0.67\right) .{ }^{[26]}$ Solutions of the standard or of the Gd complex containing DPBF $5.2 \times 10^{-5} \mathrm{M}$, prepared in the dark, were irradiated at $672 \mathrm{~nm}\left(A_{672}=0.6\right)$ by using an irradiation set-up composed by a $150 \mathrm{~W}$ xenon lamp (LOT) and a Omni- $\lambda 150$ monochromator (Zolix), under continuous stirring. The light intensity was $12 \mathrm{~mW} \mathrm{~cm}^{-2}$. The singlet oxygen quantum yield of the sample $\left(\phi_{\Delta}\right)$ were determined by using Equation (1):

$$
\phi_{\Delta}=\phi_{\Delta}^{\mathrm{std}} \frac{R \cdot \cdot_{\mathrm{abs}}^{\mathrm{std}}}{R^{\mathrm{std}} \cdot l_{\mathrm{abs}}}
$$

where $R$ and $R^{\text {std }}$ are the DPBF degradation rates for the sample and the standard, respectively, and $l_{\text {abs }} \mathbf{\square} \mathbf{\square o k}$ ? $\square$ is the intensity of absorption at the excitation wavelength calculated as described in reference. ${ }^{[30]} \mathrm{NaN}_{3}$ was used at the concentration of $5.0 \times 10^{-2} \mathrm{M}$ to efficiently quench the produced singlet oxygen. ${ }^{[31]}$ Small changes in the absorption spectra of both sample and standard were observed upon the addition of $\mathrm{NaN}_{3}$.

\section{Two-photon photophysical properties}

The TPA cross-section spectra were obtained by up-conversion fluorescence measurements ${ }^{[32]}$ using an Insight Spectra-Physics $(680 \mathrm{~nm} / 1300 \mathrm{~nm})$ femtosecond laser. The excitation beam is collimated over the cell length $(10 \mathrm{~mm})$. The fluorescence, collected at $90^{\circ}$ of the excitation beam, was focused into an optical fiber connected to a spectrometer. The incident beam intensity was adjusted to ensure an intensity-squared dependence of the fluorescence over the whole spectral range. Calibration of the spectra was performed by comparison with the published $800-950 \mathrm{~nm}$ Rhodamine $B$ two-photon absorption spectrum. ${ }^{[33]}$ Below $800 \mathrm{~nm}$, a significant contribution from one-photon absorption was noticed by a non-quadratic dependency dependence of the emitted fluorescence vs the laser power and points below this wavelength were discarded.

\section{Cell culture}

HeLa cells were cultured in DMEM complete culture medium containing phenol red. They were seeded and maintained in LabTek (Lab-Tek II) or Ibidi ( $\mu$-Dish $35 \mathrm{~mm}$ Grid-500) culture flasks or petri dishes for two-photon microscopy. The Ibidi Grid 500 petri dish presents a grid with $500 \times 500 \mu \mathrm{m}$ on the glass bottom allowing an easy localization of the irradiation zones in TP-PDT experiments. MTT toxicity test were performed in tetraplicates with extempora- 
neous solutions of 3-(4,5-dimethyl-2-thiazolyl)-2,5-diphenyl-2H-tetrazolium bromide.

\section{One-photon phototoxicity tests}

One-photon phototoxicity tests were performed, as described previously, using a homemade apparatus ${ }^{[6]]}$ using $5 \mathrm{~mm} 660 \mathrm{~nm}$ Liteon LED (Mouser electronics ref. 859-LTL-353CKR-H3) adapted for black Corning 96-well special optics plates. Cells were cultured 2 days in these 96-well plates and incubated with $1 \mu \mathrm{m}$ solution of $\mathrm{Na}$ [DPP-ZnP-GdDOTA] in complete DMEM medium containing $1 \%$ DMSO for $24 \mathrm{~h}$. The plates were irradiated 1 hour and the light intensity was measured with a power-meter. The cell viability was estimated $5 \mathrm{~h}$ after irradiation as described in the cell culture paragraph.

\section{Two-photon imaging and two-photon photodynamic thera- py}

Two-photon microscopy studies were performed on a Leica SP8 inverted microscope with $x 63 \lambda$ Blue HCS plan apo objective. A Coherent Chameleon Ultra 2 laser was used for irradiation with $150 \mathrm{fs}$ pulses with a repetition rate of $80 \mathrm{MHz}$ at $\lambda_{\mathrm{ex}}=910 \mathrm{~nm}$. A region of $250 \times 250 \mu \mathrm{m}$ was irradiated $(1.4 \mu \mathrm{s} /$ pixel) with a power of about $5.9 \mathrm{~mW}$ at the back pupil of the objective.

HeLa cells were incubated $24-28 \mathrm{~h}$ with $1 \mu \mathrm{M}$ of [DPP-ZnPGdDOTA $^{-}$in DMEM culture medium containing $1 \%$ DMSO.

Before irradiation, a phase contrast image of the $\mathbf{\square}$ word missing? was taken to assess the number of cells before irradiation.

After TP-PDT irradiation, the cells were left $4 \mathrm{~h}$ in an incubator. Then, cell viability was determined by staining with Hoechst nuclear stain (a blue fluorescence indicates the nucleus of all cells) combined with Cytox orange. This later allows for detection of cells with compromised cytoplasmic membrane (an orange fluorescence indicating dead cells). Confocal images were obtained with a Leica TSP SPE microscope using two channels, one for Hoescht (ex. $405 \mathrm{~nm})$ and one for CYTOX orange $(561 \mathrm{~nm})$. We noticed that dead HeLa cells detached from the glass bottom and were therefore not detected with confocal microscopy.

A control experiment to test the viability of cells under TP irradiation in absence of the sensitizer [DPP-ZnP-GdDOTA] ${ }^{-}$(but with $1 \%$ DMSO) was performed. It showed that the cell viability was above $95 \%$ after 300 scans of irradiation, performed in the same conditions as with [DPP-ZnP-GdDOTA $]^{-}$.

\section{Relaxometric measurements}

Proton NMRD profiles ([DPP-ZnP-GdDOTA $]^{-}=1.13 \mathrm{~mm}, \mathrm{pH} 6.6$ in $\mathrm{H}_{2} \mathrm{O}$, and [DPP-ZnP-GdDOTA] ${ }^{-}=0.96 \mathrm{~mm}, \mathrm{pH} 6.85$ in aqueous $\mathrm{NaCl}$ $50 \mathrm{~mm}$ ) were recorded on a Stelar SMARTracer Fast Field Cycling relaxometer $(0.01-10 \mathrm{MHz})$ and a Bruker WP80 NMR electromagnet adapted to variable field measurements $(20-80 \mathrm{MHz})$ and controlled by a SMARTracer PC NMR console. Higher field relaxivities were measured on Bruker AVANCE NMR spectrometers at $300 \mathrm{MHz}$, $400 \mathrm{MHz}$, and $600 \mathrm{MHz}$. The temperature was monitored by a VTC91 temperature control unit and maintained by a gas flow. The temperature was determined by previous calibration with a $\mathrm{Pt}$ resistance temperature probe. The longitudinal relaxation rates (1/ $\mathrm{T}_{1}$ ) were determined in water and in aqueous $\mathrm{NaCl} 50 \mathrm{~mm}$. The least-squares fit of the ${ }^{1} \mathrm{H}$ NMRD data was performed using Visualiseur/Optimiseur ${ }^{[34]}$ running on a MATLAB 8.3.0 (R2014a) platform. The relaxivity was also measured in the presence of BSA $38 \mathrm{~g} \mathrm{~L}^{-1}$ for [DPP-ZnP-GdDOTA $]^{-}=0.23 \mathrm{~mm}$, in $\mathrm{H}_{2} \mathrm{O}$ at $298 \mathrm{~K}$ and $20 \mathrm{MHz}$. The exact Gd"I ion concentration was determined by ICP-AES analysis after microwave-assisted mineralization.

\section{Acknowledgements}

We thank Agnès Pallier for performing relaxivity measurements. The icFRC (http://wwwicfrc.fr) and Region Alsace are gratefully acknowledged for a fellowship to J.S., and the Ligue contre le Cancer for financial support. We thank warmly E. Leize, C. Perret, and H. Nierengarten for the HR mass-spectrometry determination. The Italian CNR (Project PM.P04.010 "MACOL"), MIUR project PRIN 2010CX2TLM, and MIUR-CNR project Nanomax N-CHEM are gratefully acknowledged.

Keywords: diketopyrrolopyrrole • gadolinium - magnetic resonance imaging $\cdot$ photodynamic therapy $\cdot$ porphyrins $\cdot$ twophoton absorption

[1] a) H. Cabral, N. Nishiyama, K. Kataoka, Acc. Chem. Res. 2011, 44, 9991008; b) T. Lammers, S. Aime, W. E. Hennink, G. Storm, F. Kiessling, Acc. Chem. Res. 2011, 44, 1029-1038.

[2] P. Caravan, J. J. Ellison, T. J. McMurry, R. B. Lauffer, Chem. Rev. 1999, 99, $2293-2352$.

[3] E. Tóth, L. Helm,A. E. Merbach in The Chemistry of Contrast Agents in Medical Magnetic Resonance Imaging, 2nd edn. Wiley and Sons, New York, Relaxivity of Gadolinium(III) Complexes (Chapter 2) 2013, pp. 25 82.

[4] E. J. Werner, A. Datta, C. J. Jocher, K. N. Raymond, Angew. Chem. Int. Ed. 2008, 47, 8568-8580; Angew. Chem. 2008, 120, 8696-8709.

[5] a) T. J. Dougherty, C. J. Gomer, B. W. Henderson, G. Jori, D. Kessel, M. Korbelik, J. Moan, Q. Peng, J. Nat. Cancer Inst. 1998, 90, 889-905; b) C. W. Brian, S. P. Michael, Phys. Med. Chem. 2008, 53, R61; c) M. Ethirajan, Y. Chen, P. Joshi, R. K. Pandey, Chem. Soc. Rev. 2011, 40, 340-362.

[6] a) K. Ogawa, H. Hasegawa, Y. Inaba, Y. Kobuke, H. Inouye, Y. Kanemitsu, E. Kohno, T. Hirano, S.-i. Ogura, I. Okura, J. Med. Chem. 2006, 49, $2276-$ 2283 ; b) M. A. Oar, W. R. Dichtel, J. M. Serin, J. M. J. Fréchet, J. E. Rogers, J. E. Slagle, P. A. Fleitz, L.-S. Tan, T. Y. Ohulchanskyy, P. N. Prasad, Chem Mater. 2006, 18, 3682-3692; c) M. Khurana, H. A. Collins, A. Karotki, H. L. Anderson, D. T. Cramb, B. C. Wilson, Photochem. Photobiol. 2007 83, $1441-1448$; d) H. A. Collins, M. Khurana, E. H. Moriyama, A. Mariampillai, E. Dahlstedt, M. Balaz, M. K. Kuimova, M. Drobizhev, X. D. YangVictor, D. Phillips, A. Rebane, B. C. Wilson, H. L. Anderson, Nat. Photonics 2008, 2, 420-424; e) J. R. Starkey, A. K. Rebane, M. A. Drobizhev, F. Meng, A. Gong, A. Elliott, K. Mclnnerney, C. W. Spangler, Clin. Cancer Res. 2008, 14, 6564-6573; f) E. Dahlstedt, H. A. Collins, M. Balaz, M. K. Kuimova, M. Khurana, B. C. Wilson, D. Phillips, H. L. Anderson, Org. Biomol. Chem. 2009, 7, 897-904; g) M. Pawlicki, H. A. Collins, R. G. Denning, H. L. Anderson, Angew. Chem. Int. Ed. 2009, 48, 3244-3266 Angew. Chem. 2009, 121, 3292-3316.

[7] J. P. Celli, B. Q. Spring, I. Rizvi, C. L. Evans, K. S. Samkoe, S. Verma, B. W. Pogue, T. Hasan, Chem. Rev. 2010, 110, 2795-2838.

[8] M. Montaldi, A. Credi, L. Prodi, M. T. Gandolfi in Vol. Handbook of Photochemistry, 3rd ed., CRC Press, Taylor \& Francis, Boca Ration, 2006, p. 620.

[9] a) G. Li, A. Slansky, M. P. Dobhal, L. N. Goswami, A. Graham, Y. Chen, P. Kanter, R. A. Alberico, J. Spernyak, J. Morgan, R. Mazurchuk, A. Oseroff, Z. Grossman, R. K. Pandey, Bioconjugate Chem. 2005, 16, 32-42; b) L. N. Goswami, W. H. White, J. A. Spernyak, M. Ethirajan, Y. Chen, J. R. Missert, J. Morgan, R. Mazurchuk, R. K. Pandey, Bioconjugate Chem. 2010, 21, 816-827; c) J. A. Spernyak, W. H. White, M. Ethirajan, N. J. Patel, L. Goswami, Y. Chen, S. Turowski, J. R. Missert, C. Batt, R. Mazurchuk, R. K. Pandey, Bioconjugate Chem. 2010, 21, 828-835; d) J. Luo, L.-F. Chen, P. Hu, Z.-N. Chen, Inorg. Chem. 2014, 53, 4184-4191; e) K. S. Samkoe, A. Chen, I. Rizvi, J. A. O'Hara, J. P. Hoopes, T. Hasan, B. W. Pogue in Optical 
Methods for Tumor Treatment and Detection: Mechanisms and Techniques in Photodynamic Therapy XVIII, Vol. 7164 (Ed.: D. H. Kessel), 2009 p. 71640D; f) D. Aydın Tekdaş, R. Garifullin, B. Şentürk, Y. Zorlu, U. Gundogdu, E. Atalar, A. B. Tekinay, A. A. Chernonosov, Y. Yerli, F. Dumoulin, M. O. Guler, V. Ahsen, A. G. Gürek, Photochem. Photobiol. 2014, 90, 1376-1386; g) H. Haroon-Ur-Rashid, M. N. Umar, K. Khan, M. N. Anjum, M. Yaseen, J. Struct. Chem. 2014, 55, 910-915.

[10] a) R. Kopelman, Y.-E. Lee Koo, M. Philbert, B. A. Moffat, G. Ramachandra Reddy, P. McConville, D. E. Hall, T. L. Chenevert, M. S. Bhojani, S. M. Buck A. Rehemtulla, B. D. Ross, J. Magn. Magn. Mater. 2005, 293, 404-410 b) G. R. Reddy, M. S. Bhojani, P. McConville, J. Moody, B. A. Moffat, D. E. Hall, G. Kim, Y.-E. L. Koo, M. J. Woolliscroft, J. V. Sugai, T. D. Johnson, M. A. Philbert, R. Kopelman, A. Rehemtulla, B. D. Ross, Clin. Cancer Res. 2006, 12, 6677-6686; c) J. R. McCarthy, F. A. Jaffer, R. Weissleder, Smal 2006, 2, 983-987; d) C.-W. Lai, Y.-H. Wang, C.-H. Lai, M.-J. Yang, C.-Y. Chen, P.-T. Chou, C.-S. Chan, Y. Chi, Y.-C. Chen, J.-K. Hsiao, Small 2008, 4 218-224; e) A. Vaidya, Y. Sun, Y. Feng, L. Emerson, E.-K. Jeong, Z.-R. Lu, Pharm. Res. 2008, 25, 2002-2011; f) X. Liang, X. Li, L. Jing, X. Yue, Z. Dai, Biomaterials 2014, 35, 6379-6388; g) H.-J. Yoon, T. G. Lim, J.-H. Kim, Y. M. Cho, Y. S. Kim, U. S. Chung, J. H. Kim, B. W. Choi, W.-G. Koh, W.-D. Jang, Biomacromolecules 2014, 15, 1382-1389.

[11] J. Schmitt, V. Heitz, A. Sour, F. Bolze, H. Ftouni, J.-F. Nicoud, L. Flamigni, B. Ventura, Angew. Chem. Int. Ed. 2015, 54, 169-173; Angew. Chem. 2015, 127, 171-175.

[12] J. Henig, E. Tóth, J. Engelmann, S. Gottschalk, H. A. Mayer, Inorg. Chem. 2010, 49, 6124-6138.

[13] T. Odani, S. Okada, C. Kabuto, T. Kimura, S. Shimada, H. Matsuda, H. Oikawa, A. Matsumoto, H. Nakanishi, Cryst. Growth Des. 2009, 9, 3481 3487.

[14] L. Vander Elst, M. Port, I. Raynal, C. Simonot, R. N. Muller, Eur. J. Inorg. Chem. 2003, 2495-2501.

[15] A. Carné-Sánchez, C. S. Bonnet, I. Imaz, J. Lorenzo, É. Tóth, D. Maspoch, J. Am. Chem. Soc. 2013, 135, 17711-17714

[16] J. W. Fredy, J. Scelle, A. Guenet, E. Morel, S. Adam de Beaumais, M. Ménand, V. Marvaud, C. S. Bonnet, E. Tóth, M. Sollogoub, G. Vives, B. Hasenknopf, Chem. Eur. J. 2014, 20, 10915-10920.

[17] a) A. Martins, J.-F. Morfin, C. G. C. Geraldes, É. Tóth, J. Biol. Inorg. Chem. 2014, 19, $281-295$; b) G. Nicolle, É. Tóth, K.-P. Eisenwiener, H. Mäcke, A Merbach, J. Biol. Inorg. Chem. 2002, 7, 757-769.

[18] M. F. Ferreira, J. Goncalves, B. Mousavi, M. I. M. Prata, S. P. J. Rodrigues, D. Calle, P. Lopez-Larrubia, S. Cerdan, T. B. Rodrigues, P. M. Ferreira, L. Helm, J. A. Martins, C. F. G. C. Geraldes, Dalton Trans. 2015, 44, 40164031.
[19] R. F. Pasternack, P. R. Huber, P. Boyd, G. Engasser, L. Francesconi, E. Gibbs, P. Fasella, G. Cerio Venturo, L. d. Hinds, J. Am. Chem. Soc. 1972, 94, $4511-4517$.

[20] a) J. Costa, E. Balogh, V. Turcry, R. Tripier, M. Le Baccon, F. Chuburu, H. Handel, L. Helm, É. Tóth, A. E. Merbach, Chem. Eur. J. 2006, 12, 6841 6851 ; b) M. Regueiro-Figueroa, A. Nonat, G. A. Rolla, D. Esteban-Gómez, A. de Blas, T. Rodríguez-Blas, L. J. Charbonnière, M. Botta, C. Platas-Iglesias, Chem. Eur. J. 2013, 19, 11696-11706; c) H. Jaccard, P. Miéville, C. Cannizzo, C. Mayer, L. Helm, J. Biol. Inorg. Chem. 2014, 19, 145-159; d) S. Aime, C. Cabella, S. Colombatto, S. Geninatti Crich, E. Gianolio, F.

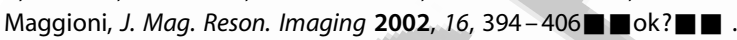

[21] É. Tóth, L. Helm, K. E. Kellar, A. E. Merbach, Chem. Eur. J. 1999, 5, 1202 1211.

[22] D. H. Powell, O. M. N. Dhubhghaill, D. Pubanz, L. Helm, Y. S. Lebedev, W. Schlaepfer, A. E. Merbach, J. Am. Chem. Soc. 1996, 118, 9333-9346.

[23] J. B. Livramento, A. Sour, A. Borel, A. E. Merbach, É. Tóth, Chem. Eur. J. 2006, 12, 989- 1003 .

[24] S. Aime, M. Botta, M. Fasano and E. Terreno in The chemistry of contrast agents in medical magnetic resonance imaging, Vol. Eds.: J. Wiley and Sons), Protein-bound metal chelates, 2001, pp. 193-242.

[25] F. Wilkinson, J. G. Brummer, J. Phys. Chem. Ref. Data 1981, 10, 8091000.

[26] A. Ogunsipe, J.-Y. Chen, T. Nyokong, New J. Chem. 2004, 28, 822-827.

[27] P. G. Seybold, M. Gouterman, J. Mol. Spectrosc. 1969, 31, 1-13.

[28] J. J. M. Lamberts, D. R. Schumacher, D. C. Neckers, J. Am. Chem. Soc $1984,106,5879-5883$.

[29] C. Tanielian, C. Wolff, M. Esch, J. Phys. Chem. 1996, 100, 6555-6560.

[30] I. Seotsanyana-Mokhosi, N. Kuznetsova, T. Nyokong, J. Photochem. Photobiol. A 2001, 140, 215-222.

[31] M. J. Moreno, E. Monson, R. G. Reddy, A. Rehemtulla, B. D. Ross, M. Philbert, R. J. Schneider, R. Kopelman, Sensor Actuat. B Chem. 2003, 90, 82

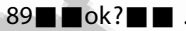

[32] A. Hayek, F. Bolze, C. Bourgogne, P. L. Baldeck, P. Didier, Y. Arntz, Y. Mély, J.-F. Nicoud, Inorg. Chem. 2009, 48, 9112-9119.

[33] C. Xu, W. W. Webb, J. Opt. Soc. Am. B 1996, 13, 481-491.

[34] F. Yerly in VISUALISEUR 2.3.5, OPTIMISEUR 2.3.5, Vol. Lausanne, Switzerland, 1999.

Received: August 28, 2015

Published online on $\mathbf{m}$ II, 0000 


\section{FULL PAPER}

A bifunctional agent that combines a (diketopyrrolopyrrole)porphyrin component as a two-photon photosensitizer for photodynamic therapy (PDT) with a gadolinium(III) DOTA complex as a magnetic resonance imaging probe was synthesized. Relaxometric, photophysical, and in cell studies highlight the potential of this molecule as a theranostic agent.

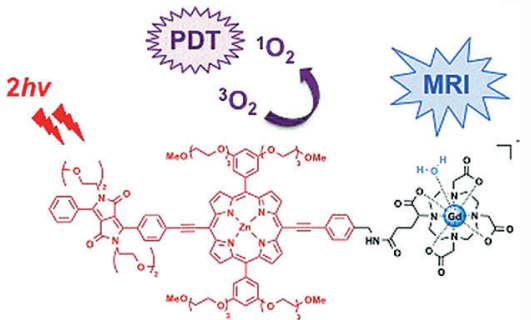

Photodynamic Therapy

J. Schmitt, V. Heitz, ${ }^{*}$ A. Sour, F. Bolze, ${ }^{*}$ P. Kessler, L. Flamigni, B. Ventura, *

C. S. Bonnet, É. Tóth*

A Theranostic Agent Combining a Two-Photon-Absorbing Photosensitizer for Photodynamic Therapy and a Gadolinium(III) Complex for MRI Detection

Please check that the ORCID identifiers listed below are correct. We encourage all authors to provide an ORCID identifier for each coauthor. ORCID is a registry that provides researchers with a unique digital identifier. Some funding agencies recommend or even require the inclusion of ORCID IDs in all published articles, and authors should consult their funding agency guidelines for details. Registration is easy and free; for further information, see http://orcid.org/.

Julie Schmitt

Valérie Heitz

Angélique Sour

Frédéric Bolze

Pascal Kessler

Lucia Flamigni

Barbara Ventura

Célia S. Bonnet

Éva Tóth 